\begin{abstract}
WARFIELD, HEATHER ANN. The Therapeutic Value of Pilgrimage: A Grounded Theory Study. (Under the direction of Stanley B. Baker and Sejal B. Parikh.)

The purpose of this constructivist grounded theory qualitative study was to explore the meaning assigned to pilgrimage experiences, to evaluate the similarities and differences between religious and non-religious pilgrimages, and to elucidate the therapeutic value of pilgrimage journeys. The theoretical underpinnings for the current study integrated historical and contemporary pilgrimage theory, personal construct theory, and multicultural counseling theory. Ten participants, who represented diverse pilgrimage experiences, were interviewed about their particular journeys. The semi-structured interview protocol was based on previous pilgrimage scholarship and psychological theory. The interview transcripts were analyzed and coded in congruence with a grounded theory research design model. In specific, initial, focused, axial, and theoretical codes were established. After validation of the four levels of codes by study participants, the investigator posited an emerging theory that pilgrimage is therapeutic in biological, psychological, social, and spiritual ways. Further, the researcher observed that pilgrimages appear to differentiate along a dimension of linearity and were classified as either linear or nonlinear. Despite this classification, both types of pilgrimages in the current study shared a sacred focus. The limitations of the study were explored and the personal and societal implications of pilgrimage were addressed. Additionally, recommendations for future research, counseling practice, and counselor training were provided. Finally, conclusions were offered regarding the promotion of pilgrimage as an antidote for the loss of soul in modern society.
\end{abstract}


(C) Copyright 2013 by Heather Ann Warfield

All Rights Reserved 
The Therapeutic Value of Pilgrimage: A Grounded Theory Study North Carolina State University

by

Heather Ann Warfield

A dissertation submitted to the Graduate Faculty of

North Carolina State University

in partial fulfillment of the

requirements for the Degree of

Doctor of Philosophy

Counseling \& Counselor Education

Raleigh, North Carolina

2013

APPROVED BY:

Dr. Stanley B. Baker

Co-Chair of Advisory Committee

Dr. Edwin R. Gerler

Dr. Malina Monaco
Dr. Sejal B. Parikh

Co-Chair of Advisory Committee 


\section{DEDICATION}

\section{The Road Not Taken}

Two roads diverged in a yellow wood, And sorry I could not travel both And be one traveler, long I stood

And looked down one as far as I could To where it bent in the undergrowth; Then took the other, as just as fair, And having perhaps the better claim Because it was grassy and wanted wear, Though as for that the passing there Had worn them really about the same, And both that morning equally lay In leaves no step had trodden black. Oh, I marked the first for another day!

Yet knowing how way leads on to way

I doubted if I should ever come back.

I shall be telling this with a sigh

Somewhere ages and ages hence:

Two roads diverged in a wood, and I, I took the one less traveled by, And that has made all the difference.

\section{Robert Frost}




\section{BIOGRAPHY}

Heather Ann Warfield was born and raised in Wyoming. She earned a bachelor's degree in psychology with a minor in women's studies from The College of St. Scholastica. She subsequently graduated with a master's degree in psychology with an emphasis on marriage and family therapy from Chapman University. After graduation, Heather worked with children, adolescents, and their families as the site coordinator for a mental health and substance abuse treatment program. These professional and educational experiences led to an interest in the intersection of spirituality with identity development, ethical decision-making, and the internationalization of the counseling profession. As a result of these interests, Heather pursued doctoral work in Counseling \& Counselor Education at North Carolina State University and focused on international counseling. As a doctoral student, Heather published and presented at state and national conferences on the topics of ethical decision-making, pilgrimage, and international counseling. 


\section{ACKNOWLEDGEMENTS}

I want to thank my husband and best friend, Stephen, for your overwhelming inspiration and support during my doctoral studies. You and our three children have sacrificed in so many ways to make this possible.

Thank you to my parents, William and Kathleen, for raising me in an environment that provided the space to dream and the natural beauty that will always beckon me to return home. Thank you to my sister, Valerie, who shares a deep desire to explore the world and who valiantly fights for all that is honorable.

Thank you, Dr. Stanley Baker, for your mentorship, encouragement, and expertise. Thank you, Dr. Sejal Parikh, for your guidance and investment in my scholarship. I also want to thank my committee members, Drs. Edwin Gerler, Helen Lupton-Smith, and Malina Monaco who have contributed to this dissertation through their enthusiasm and collaboration - I am honored to know you. Additionally, thank you Dr. Sylvia Nassar-McMillan for the opportunity to work with you and for contributing to my personal and professional growth.

Thank you to my friends at NCSU who have provided much support and shared humor through this educational and life process.

I also want to express my deep appreciation of and gratitude for the participants in my study. You are special individuals who gave me a glimpse into a private arena of your lives and your narratives have transformed me.

Finally, I want to recognize every pilgrim, who for millennia, has set forth on a journey in order to nurture your soul. Your radical departure from routine has given my life meaning. 


\section{TABLE OF CONTENTS}

LIST OF TABLES ....................................................................................... vii

CHAPTER ONE: INTRODUCTION

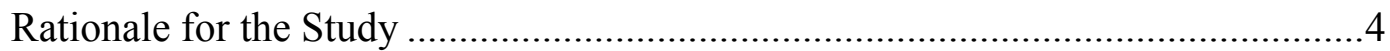

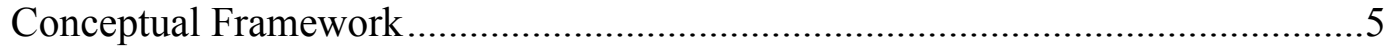

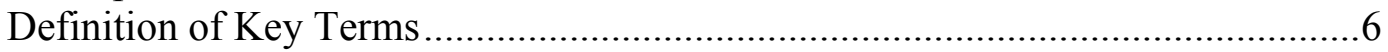

Purpose of the Study ................................................................................. 7

CHAPTER TWO: LITERATURE REVIEW .........................................................

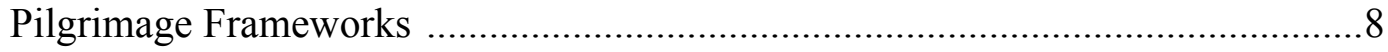

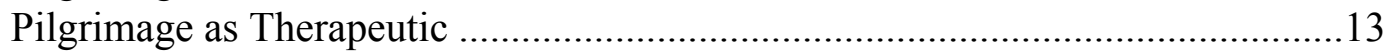

The Process of Pilgrimage ........................................................................... 17

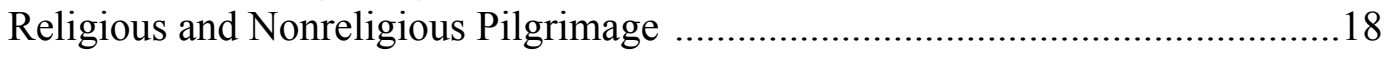

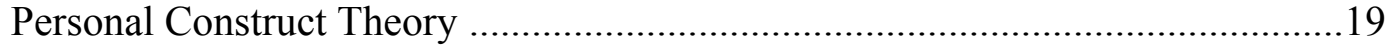

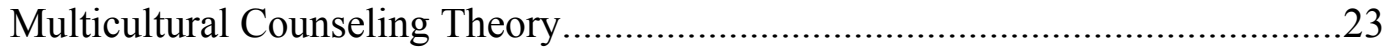

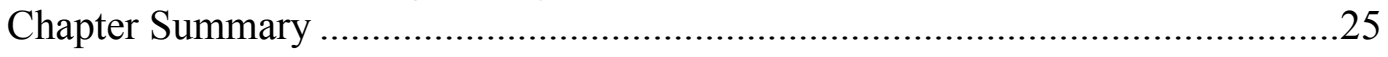

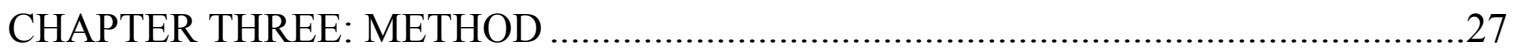

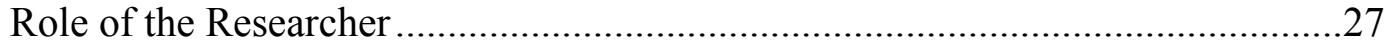

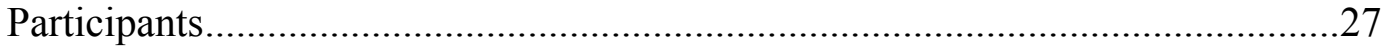

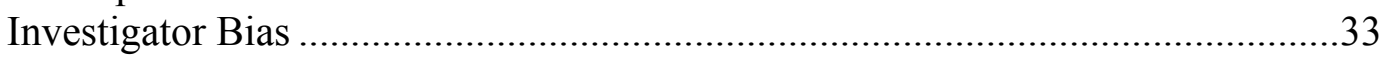

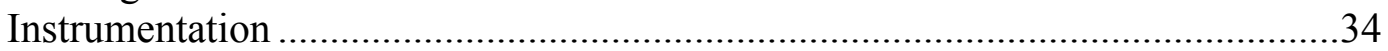

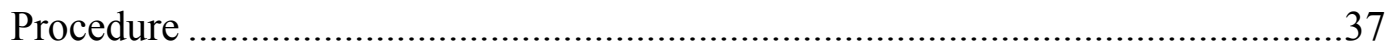

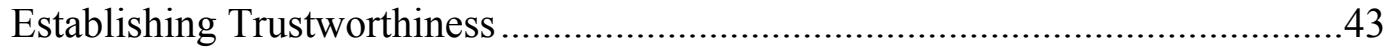

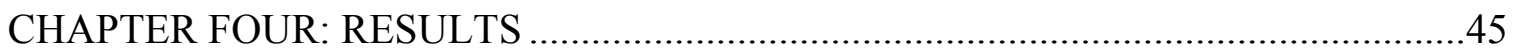

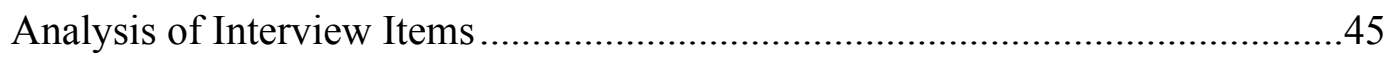

Construction of Grounded Theory ............................................................58

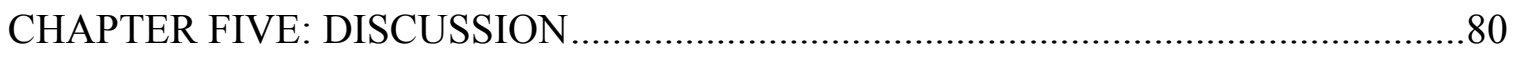

Integration of Study Results Theory and Research ......................................... 80

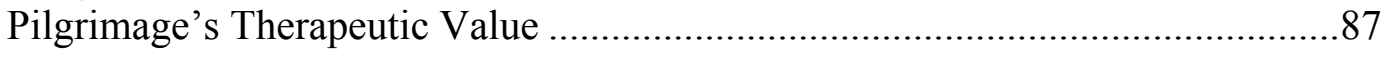

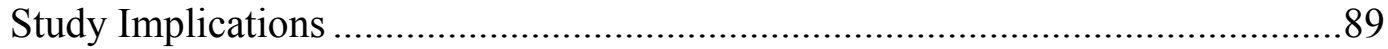

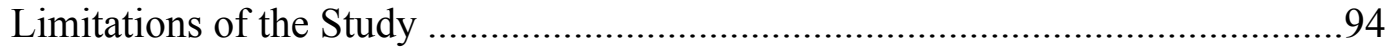

Recommendations for Future Research and Practice .........................................95

Conclusion ............................................................................................... 96

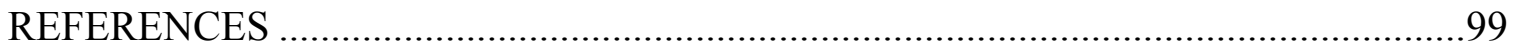

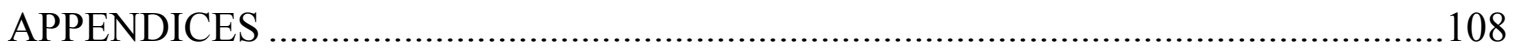

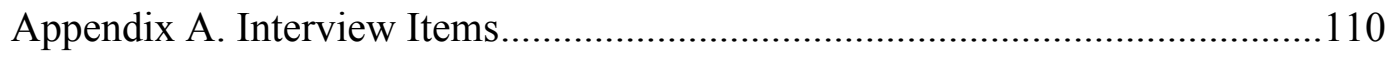


Appendix B. North Carolina State University Informed Consent ......................113

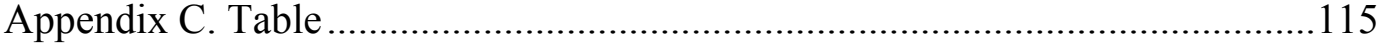




\section{LIST OF TABLES}

Table 1: Initial, Focused, Axial, and Theoretical Codes Identified During Analysis......115 


\section{CHAPTER ONE: INTRODUCTION}

Every year, millions of people around the world participate in pilgrimage journeys. These journeys occur in nearly every region of the world with nearly every type of people. Motivations to embark on pilgrimages include the desire to: fulfill a vow; undergo a rite of passage; experience the educational or emotional benefits of religious or secular tourism; witness a recurring miracle; reaffirm ethnic or religious identity; reenact a religious event; atone for a transgression; comply with an obligation; or be healed (Davidson \& Gitlitz, 2002). A component of each of the above motives is the idea that the pilgrimage journey may be therapeutic in some manner. There has been ample documentation of the connection between religious pilgrimage and specific acts of healing--perceived as miraculous by some and explained scientifically by others (Davidson \& Gitlitz, 2002; Gopal \& Dubey, 1990; Morinis, 1992; Winkleman \& Dubisch, 2005). In addition to accounts of healing through religious pilgrimages, Winkleman and Dubisch noted that nonreligious pilgrimages, among other characteristics, include the "transformative nature of the undertaking, including the transformation from illness to health" (2005, p. xv).

In a recent study conducted in the Netherlands, ailing older Roman Catholic adults participated in a pilgrimage to Lourdes, France in which they were accompanied by multiple medical professionals, including doctors, nurses, physiotherapists and nursing trainees. Also accompanying the pilgrims were priests, nuns, pastoral workers, and deacons. The goal of the pilgrimage was to "communicate private traumas that are no longer dealt with in the church and for which no rituals are ordinarily available" (Notermans, 2007, p. 4). Prior to the pilgrimage, the pilgrims reported being depressed by losses they could not communicate in 
the biomedical domain, to their family, or to their church. During the pilgrimage, the pilgrims gained a narrative framework for coping with their past pain, and after the pilgrimage, reported that they experienced emotional healing regarding their previously silenced pain. Additionally, the pilgrimage provided a communal structure with similar individuals who moved through the rituals together (Notermans, 2007).

Dubisch described her pilgrimage experience as part of the annual motorcycle journey called "Run for the Wall," an expedition from California to the Vietnam Veterans Memorial in Washington, D.C. The participants of this annual motorcycle journey are veterans of Vietnam and future conflicts as well as those who support the military in some fashion. This event is classified as a secular pilgrimage and is classified as a pilgrimage because the participants separate from ordinary life, the journey is made under conditions of danger and hardship, the rituals along the way pay tribute to the dead or missing military troops, there is a sense of liminality created by the roar of hundreds of motorcycles, and there is a "sacred" destination. In addition, the participants reported a transformative nature to this event (Dubisch, 2005). This transformation includes the fact that the "Run" is a ritual, which has been recognized as a healing process (Walter, 1993). Additionally, the "Run" provides a sense of community, creates a new narrative of the events surrounding the Vietnam War, provides a context for grieving, and provides a sense of support in which veterans can deal with such issues as guilt, alienation, post-traumatic stress disorder, and loss (Dubisch, 2005).

In addition to the reports of healing cited above, pilgrimage has a long history within Christianity, Judaism, Islam, Hinduism, and Buddhism of addressing such issues as sin, guilt, impurity, and salvation. For example, Gopal and Dubey (1990) reported that, within bhakti 
oriented Hinduism, pilgrimage is seen as superior to sacrifice and the pilgrim could expect such benefits as purification and forgiveness of sins. Within Islam, one of the five tenets of the faith is a pilgrimage to Mecca, Saudi Arabia -- known as the Hajj. This pilgrimage occurs once per year and is required of all healthy males at least once in their lifetime. The primary focus of the Hajj is the Ka'aba, a cubical granite structure that is believed to be the site upon which Abraham offered his son Ishmael as a sacrifice to God. The benefits of the pilgrimage for the pilgrim are a reinforced sense of religious identity, connection with the divine, and a fulfillment of a religious obligation. Another type of religious pilgrimage that is undertaken by Jewish women is the visit to the tombs of the three Rachels in Israel. The overarching themes of this type of pilgrimage are illness, exile, healing, and female gender. The pilgrims visit the tombs of Rachel, the biblical wife of the patriarch, Jacob, Rachel the historical late nineteenth and early twentieth century poetress, and Rachel, the wife of Rabbi Akiva. The pilgrims believe there is a connection with these women regarding illness and exile. Through this connection, Jewish women report feeling "understood," which is construed as a healing experience (Sered, 2005).

The pilgrimage examples cited above reflect documented accounts of healing as reported by the pilgrims. The healing dynamics of these pilgrimages include: physical, social, and symbolic effects; acts of personal empowerment; the belief that the individuals' identity in relationship to sacred others integrates the self within collective models; the particularizing of individual suffering with a broader framework of meaning; a sense of solidarity with a community of fellow pilgrims; and an alteration of consciousness that elicits psychophysiological dynamics that support a range of bodily healing responses (Winkleman 
$\&$ Dubisch, 2005). Thus, the reported experiences of pilgrims, in conjunction with observations by scholars, is the basis for the claim that the there is therapeutic value in the pilgrimage journey.

\section{Rationale for the Study}

Despite the anecdotal evidence, as well as the well-documented accounts of healing and transformation, the counseling literature is silent on the global pilgrimage phenomenon. Further evidence of this silence includes a sizable conference that was convened in 1988 at the Roehampton Institute of Higher Education in London to focus on the interdisciplinary study of the topic of pilgrimage. Present at the conference were anthropologists, geographers, historians, theologians, priests, and pilgrims--appropriate due to the volumes of data that have been published from these sources. However, absent from the conference were representatives from the domains of psychology and counseling. One explanation for this absence is that little research has been conducted to ascertain the psychological and emotional implications of pilgrimage on individuals. The individual experience, and the meaning-making that occurs before, during, and after the pilgrimage have been addressed by one prominent scholar as the primary area for future research on the topic of pilgrimage (Morinis, 1992). Scholars within the counseling profession are in an ideal position to explore these individual experiences as the paradigmatic framework is conducive to the exploration of issues affecting individuals and small groups over and above societal trends. The present study is an exploration of the therapeutic value of the pilgrimage experience as described by individual pilgrims. 


\section{Conceptual Framework}

The conceptual context of a study - "the system of concepts, assumptions, expectations, beliefs, and theories that supports your research is a key part of your design" (Maxwell, 1996, p. 25). There are several of these conceptual frameworks that were integrated in the present study. The first overarching framework was the collection of works that comprise perspectives on pilgrimage. This collection will be delineated into three frameworks: pilgrimage as a site-specific phenomenon; pilgrimage as a social phenomenon; and pilgrimage as an individual phenomenon. Additionally, previous literature about the nature of pilgrimage as therapeutic was explored as was the process of pilgrimage. This process included specific steps that a pilgrim encounters along the journey. Further, a comparison of religious and secular pilgrimage was explored. Since the focus of the current study is on the meaning created by the individual pilgrim, the framework for explicating this meaning-making is personal construct theory. The notion of constructs and meaning created by the individual as a scientist, active in his or her own life, was developed by George Kelly (1955). The premise of the theory is that individuals construct and reconstruct meaning throughout their lifetimes (Carver \& Scheier, 1996). This contructivist paradigm of meaning is a core principle of the multicultural paradigm. Thus, the multicultural counseling movement that has embraced this constructivist approach is discussed in relation to the pilgrimage phenomenon. These discussions focus on clients' lives as well as the personal and professional lives of the counselor . 


\section{Definition of Key Terms}

The term pilgrimage has been widely used in a variety of contexts with little regard for specificity. In response to this, as well as their own empirical study on the topic, prominent pilgrimage scholars have concluded, "If one can no longer take for granted the meaning of a pilgrimage for its participants, one can no longer take for granted a uniform definition of the phenomenon of 'pilgrimage' either" (Eade \& Sallnow, 1991, p. 3). Thus, for the current study, the definition of pilgrimage is based on a convergence of prior definitions: "Pilgrimage is an experience that occurs within a specific time and space with a theophanic destination (Pace, 1989) in which the pilgrim's mental capacities and emotions are engaged (Winkelman \& Dubisch, 2005) as well as in which the pilgrim relates to fellow pilgrims sharing in the journey (Pace, 1989; Turner, 1969; Turner, 1974; Turner \& Turner, 1978; Winkelman \& Dubisch, 2005) and in which the pilgrim connects with the divine in some manner" (McKevitt, 1991; Winkelman \& Dubisch, 2005).

Webster's II: New College Dictionary (2001) defines therapeutic as an adjective that means, "having healing powers." Further, value is defined as, "worth in usefulness or importance to the possessor" and "a principle, standard, or quality regarded as worthwhile or desirable." Thus, therapeutic value is that which has healing powers that are worthwhile, desirable, useful, or important to the possessor. Of paramount significance to the current study is the role of the possessor or respondent in assigning value to a particular phenomenon. While the term therapeutic value is used frequently in publications, it is rarely defined. A review of various types of literature revealed the therapeutic value of the following: storytelling (Dwivedi, 1997); adversity (Gordon, 2011); specific medical 
procedures (JAMA, 2009, Nagashima \& Kasanuki, 2003; O'Sullivan, 2007); food (Zhou, 2009); and pharmaceutical drugs (Bush, 2010; Kantrowitz \& Citrome, 2007; Kenreigh, Wagner, \& Chrisp, 2006). In the previous literature on therapeutically valuable procedures or experiences, pilgrimage has not been an area of focus. However, in a recent publication, Dubisch and Winkleman noted the healing characteristics of pilgrimage and alluded to its therapeutic nature (2005).

\section{Purpose of the Study}

The purpose of this study was to examine the pilgrimage experiences of individuals. The research questions were: How is a pilgrimage journey therapeutic? What meaning is assigned to various points in the pilgrimage process? and How are religious and nonreligious pilgrimage experiences similar or different? 


\section{CHAPTER TWO: LITERATURE REVIEW}

This section focuses on the previous literature about the topic of pilgrimage. The literature has been delineated by pilgrimage frameworks that explore the pilgrimage site, the social phenomenon of pilgrimage, and the individual meaning of pilgrimage. In addition, ethnographic research was examined for therapeutic themes and the stepwise process of pilgrimage was explored. Moreover, emerging literature on the topic of secular pilgrimage was compared with the traditional focus on religious pilgrimage and an analysis of the two was offered. To explain the meaning created by individual pilgrims about their journeys, personal construct theory was examined and its relevance to the realm of pilgrimage research was demonstrated. Lastly, pilgrimage was introduced into the counseling domain through the door of multicultural counseling. An overview of the multicultural movement was provided and the specific applicability of pilgrimage within a counseling paradigm was established.

\section{Pilgrimage Frameworks}

Dubisch and Winkleman (2005) defined pilgrimage as "special or sacred journey" in contrast to mundane forms of travel and asserted that the journey's significance comes from the totality of the event (p.xv). Previous pilgrimage scholars have established rich descriptions of specific pilgrimage sites, analyzed the structural change that occurs as a result of the pilgrimage journey, and documented the meaning of the pilgrimage journey constructed by individuals. These three dimensions have followed a chronological trend of movement from site to process to construction of meaning. This section explicated pilgrimage as a site-specific phenomenon, pilgrimage as a social phenomenon, and pilgrimage as an individual phenomenon. In addition, the section explored the therapeutic 
attributes and actual accounts of pilgrimage as therapeutic and compared religious and secular pilgrimage.

\section{Pilgrimage as a Site-Specific Phenomenon}

Knowledge about pilgrimage sites has been gathered through the writings of anthropologists, sociologists, religious leaders, and travelers for hundreds and hundreds of years. A sacred site is recognized as being a holy place which is marked off by profane surrounding space, where heaven and earth stand intersected, and where time stands still, and where there exists the possibility to the realm of the transcendent (Eliade, 1963). According to Spencer and Spencer (2002), a site can be considered sacred because (a) certain points on the earth on believed to be inherently spiritual with an energy that can be felt, (b) the sites themselves seem to be chosen by the divinities, or (c) the sites are places into which people have invested their belief or emotion. These holy places may be physical formations such as rocks or trees, shrines to venerated saints, or places of communal worship such as a temple or church. Examples of such sites include the Ka'aba in Mecca believed to be the remains of the alter that was used by the biblical patriarch Abraham when he offered his son, Ishmael, as a sacrifice. Some also believe that the stone was brought by the archangel, Gabriel, from a nearby mountain (Davidson \& Gitlitz, 2002). In Northeast Brazil, the shrine to St. Francis, a Catholic saint known in this region of the world as St. Francis of the Wounds, is worshipped for his healing miracles. His followers believe his physical shrine embodies divine power and they flock to this shrine with various requests for healing (Greenfield \& Cavalcatne, 2005). Ninaistákis Mountain, a physical mountain at the edge of Glacier Park in Montana, is a sacred site to the Blackfoot Nation. This mountain is believed to be the home of Thunderbird, 
the most powerful of the supernatural beings and the one who gave the first medicine pipe to the Blackfoot people. Men within this community travel to the mountain for a vision quest, a ritual in which the men climb the mountain, wait for several days, fast, pray, and meditate while they wait for a vision to foretell the future or give them spiritual power (Reeves, 1994).

\section{Pilgrimage as a Social Phenomenon}

In the past two centuries, the study of pilgrimage has moved from a focus on the sacred site to the function of the pilgrimage journey within a larger societal structure. The theory of Émile Durkheim about the role of religion in society has largely influenced this perspective. Durkheim examined the way in which religion connected society and the ways in which it functioned as a type of social cohesion. He asserted that religion is an expression of society and that every society has some level of religion. Humans perceive a force greater than themselves and express this perception in social groups (Durkheim, 1947). The scholarly focus on religion within the group context, as well as the emerging attention given to fieldwork observations on religious expression, led to the prominence of the pilgrimage work of Victor and Edith Turner. As anthropologists, the Turners explored pilgrimage within the greater social context and noted that a pilgrimage journey was an anti-structure endeavor. Pilgrims move away from established roles in society into a sector that is characterized by dialectical relationships- totality and partiality, absence of property and possession of property, simplicity and complexity, absence of rank and distinctions of rank. The Turners' notions about pilgrimage reflected years of time spent with the Ndembu tribe in Africa and the intense study of initiation rites and pilgrimages in multiple societies around 
the world. Thus, the observations about pilgrimage are closely tied to rites of passage and form the basis for the process that occurs when individuals undertake a pilgrimage journey.

There are two primary constructs defined by Victor Turner in his early publications regarding pilgrimage. The first construct is liminality, which Turner defines as an entity that is "neither here nor there; they are betwixt and between the positions assigned and arrayed by law, custom, and convention" (1969, p. 95). Individuals in this category are viewed as being between two sectors. The pilgrimage represents (literally and figuratively) the process by which the two sectors are linked. The second key construct in Turner's theory is communitas, which is the Latin form of community. Turner selected the Latin term rather than the English term community to "distinguish this modality of social relationship from an area of common living" (p. 96). Moreover, Turner further elucidated his conceptualization of communitas by stating, "Certain fixed offices in tribal societies have many sacred attributes; indeed, every social position has some sacred characteristics. But this 'sacred' component is acquired by the incumbents of positions during the rites of passage, through which they changed positions" (pp. 96-97). With regards to the relationship of communitas to pilgrimage, Turner suggested that pilgrimage creates communitas and that this communitas is a key factor for the pilgrimage. In specific, Turner noted three types of communitas. The first type is existential communitas that is, "the direct, immediate, and total confrontation of human identities which tends to make those experiencing it think of mankind as a homogenous, unstructured, and free community" (1974, p. 169). The second type of communitas is normative communitas that begins with a non-utilitarian experience that evolves into a structured social system based on the needs of the group to mobilize and organize resources to keep the members 
thriving. The third type of communitas is ideological communitas, which applies to a myriad of utopian models or blueprints of societies believed to exemplify or supply the optimal conditions for the community Therefore, Turner concluded that pilgrimages were journeys in which pilgrims were in a place of limbo between one state and another and characterized by the formation of one of three types of communitas (1974).

Classification. Turner and Turner (1978) asserted that all pilgrimage sites are believed to be places where miracles “once happened, still happen, and may happen again" (p. 6). They further classified pilgrimage into four types. The first type is the prototypical pilgrimage, which was established by the founder of a historical religion, his or her first disciples, or by important national evangelists of the faith. Examples of this type of pilgrimage include Jerusalem for Jews and Christians, Mecca for Muslims, Benares and Mount Kailas for Hindus, and Kandy for Buddhists. The second type of pilgrimage is the archaic pilgrimage, which is characterized by evident traces of syncretism with older religious beliefs and symbols. Examples of this type of pilgrimage are Glastonbury in England's Somerset with its Celtic pagan overtones, Chalma in Mexico with its Ocuiltecan and Aztec characteristics, and Pandharpur in the Deccan of India in which Dravidian, preIndo-European associations can be found. The third type of pilgrimage classified by Turner is the medieval pilgrimage. This type of pilgrimage is best known in the popular and literary traditions of the Christian/European Middle Ages (approximately 500-1400CE). Examples of this type of pilgrimage are Canterbury in England, Compostela in Spain, Chartres in France, Assisi in Italy, and Cologne in Germany. The fourth type of pilgrimage is the modern pilgrimage. This type of pilgrimage is characterized by a highly devotional tone and personal 
piety of the adherents. Further, it seems to represent a system of opposition against the advancing secularization of the post-Darwinian world.

\section{Pilgrimage as an Individual Phenomenon}

Due to the postmodern movement and the approach by researchers to extol humanistic virtues of a subjective, interpretive perspective to the study of human group life (Corbin \& Strauss, 2008), the realm of pilgrimage research has moved towards a greater attention to the individual meaning of both the site and the journey. This individual meaning is ascertained by researchers through the pilgrim's own words and experiences. The research method most commonly utilized by these researchers is ethnography, which is a firsthand exploration of a social or cultural setting (Salkind, 2010). This pilgrimage fieldwork is conducted by researchers in a manner in which the researcher takes on the pilgrim identity and completes the journey with the participants. Publications of ethnographic work have addressed the impact of pilgrimages on local residents (McKevitt, 1991) and accounts of healing reported by individual pilgrims (Dubisch, 2005; Gemzöe, 2005; Greenfield \& Cavalcante, 2005; \& King, 2005). The increased attention given to individual pilgrims is framed by the myriad of meanings that pilgrims construct before, during, and after a pilgrimage. Eade and Sallnow (1991) noted that there has been an analytical shift from positivist accounts of functions and features of a pilgrimage to how the practice of pilgrimage and power of shrine are constructed.

\section{Pilgrimage as Therapeutic}

In the above descriptions of pilgrimage, there is evidence of meaningful individual and social connection. This connection extends to the notion that pilgrimage is therapeutic. 
Winkelman and Dubisch stated, "Pilgrimage is a 'multimedia therapy' that combines many different kinds of healing processes that are not normally found within a single healing tradition or activity.” (2005, p. xxxvi). Powerful examples of healing, as reported by individual pilgrims, are a common thread in the pilgrimage literature. In addition to these self-reports, researchers have analyzed the written petitions and prayers, as well as physical objects, that were left by pilgrimage at the pilgrimage site. Based upon the previous definition of therapeutic as "having healing powers," (Webster's II: New College Dictionary, 2001), accounts of the therapeutic value of pilgrimage will be outlined in this section.

In one ethnographic study in central Portugal's Leiria region, the researcher revisited the account of the appearance of the Virgin Mary to three child shepherds on the thirteenth day of each month from May to October in 1917. As a result of these apparitions, the site has become sacred for Roman Catholics and is visited by two million pilgrims per year. The shrine at the site, the sanctuary of Our Lady of Fátima, is the focal point of the pilgrimage. Pilgrims, often women, make vows to the Virgin Mary for a variety of reasons. Within these reasons, healing is a frequent theme (Gemzöe, 2005). The practice of making vows is common in the Roman Catholic and Eastern Orthodox world (Christian, 1989). These vows are conditional prayers in which the devotee asks Mary for a particular request (e.g., safety, healing, fertility, etc.). Upon the request being fulfilled, the devotee performs a certain act in honor of Mary. Often, this act is a pilgrimage to the sanctuary of Our Lady of Fátima (for European devotees). Once at the shrine, the pilgrim often relinquishes a wax model of the part of the body that has been cured (Gemzöe, 2005). As a result, researchers have observed 
a variety of wax models and have concluded acts of physical healing either at the shrine or as the impetus for the pilgrimage journey.

In another published ethnography completed at the tomb of Rachel, (the biblical matriarch and wife of Jacob), researchers have found "Pilgrims Days Books" in which pilgrims signed their names, possibly where they were from, and short prayers. In the 1940s, these books indicated that multiple groups of children, who had escaped Nazi Europe (and many who had escaped the Buchenwald concentration camp), visited the tomb and lit candles. The mere fact that these children made a journey to the tomb reflects a hope for healing. In the decade prior to the 1940 s, the tomb grew in its significance to the Jewish people who "stood between extinction and redemption" (Sered, 2005, p. 74). The matriarch, Rachel, was viewed as a mother to all of Israel and was, in a sense, calling her children forth from their scattered locations around the world. Thus, the act of the immigrant children, likely orphaned, visiting the tomb was a powerful act and symbol of individual and societal healing for the Jewish people.

In an additional ethnographic publication, the principal investigator explored the Christian pilgrimage site of Walsingham, a small village in a remote region of England, at which pilgrims number a quarter of a million on an annual basis. There are both Anglican and Catholic shrines at the location and the site itself represents the fragmented religious history of the United Kingdom. Historically, pilgrims have traveled to Walsingham in search of physical healing and there are reports of miraculous healings at the site (Fisher, 1979). However, in the contemporary view of the site, "the 'healing' that is offered and sought by pilgrims includes but goes beyond the physical, into realms of social, psychological, spiritual, 
and even material 'well-being."' (Coleman, 2005, p. 94). An example of the therapeutic value of the Walsingham pilgrimage is illustrated by a man named Paul who was raised as a Roman Catholic, but lost his faith as a young man. His family and extended family made the pilgrimage journey on an annual basis as a way of affirming their pious devotion. When interviewed by a pilgrimage scholar, Paul reported that he avoided the primary procession to the site, but was able to rejoin the family outside the shrine. This act of rejoining the family was deeply meaningful to the man as he perceived a sense of restoration with his family and a connection between the institutions of family and religion (Coleman, 2005).

As mentioned previously, the annual motorcycle journey called "Run for the Wall" is comprised of individuals and groups that support the military in some fashion. They are returning veterans, family and friends of veterans, or those who desire honor American veterans. This pilgrimage occurs over the course of approximately ten days and the motorcycle route extends from California to the Vietnam Wall. Noted anthropologists, Winkleman and Dubisch, stated in response to their ethnographic work:

Dubisch's description of Vietnam veterans Run for the Wall, for example, illustrates the contemporary role of pilgrimage in addressing the psychosocial wounds of trauma and abandonment and neglect by society. The collective support provides a context for grieving, addressing guilt, and reconnecting with dead comrades. The social dynamics of this pilgrimage address emotional traumas by constructing a coherent sense of self, removing the negative stigma associated with the past, and creating a sense of pride and self-respect. This healing process transforms personal consciousness, as well as public and social 
consciousness regarding veterans, providing social support and bonds of brotherhood that empower self-transformation. (2005, p. xxx)

\section{The Process of Pilgrimage}

In addition to the above particular accounts of therapeutic value, the comprehensive pilgrimage journey is often characterized by a series of steps, with each step building upon the previous step. As one scholar attested, the effort to connect with a "sacred other" is a healing process with developmental and healing implications (Winkleman, 2000). The first step of the process commences when the pilgrim commits to making a meaningful journey to a sacred place. From this point forward, each activity related to the journey becomes part of the pilgrimage. The activities that characterize this second step of preparation take on a "separation from normal life" pattern such as training for long distance walking, preparing to leave one's family or surroundings, obtaining a visa, arranging for time away from work or other regular responsibilities, and gathering information about the pilgrimage route or other travel logistics. Other preparatory rites may include altering one's physical appearance through shaving the head and eyebrows, ritual bathing, and applying perfumes. Additional preparatory activities may include fasting from food, drink, or sexual relations. The third step of the pilgrimage process is the actual journey to the sacred space. This stage may include gathering together with other pilgrims or retreating into oneself to focus on the upcoming connection with the sacred or divine. The movement towards the sacred space also characterizes this stage. Along the path, pilgrims may gather evidence of the journey such as some type of credential and taking pictures of specific places along the journey (such as the stations of the Via Delarosa in Jerusalem). The fourth step is the final preparation to 
enter the sacred space. Pilgrims may form organized processions, chant mantras, or engage in a specific ritual that highlights the separation of this activity from everyday life.

Following the rituals, pilgrims often become silent, remove their shoes, keep their faces focused on the shrine or sacred space, and clasp their hands as a sign of reverence. The fifth step of the pilgrimage is the actual experience at the sacred site. This stage is characterized by behaviors such as placing offerings, the appropriate type of worship (with sound or without), bell-ringing, touching a part of the sacred space, weeping, kissing the sacred object, praying in front of the image, or placing an object at the shrine. The sixth step of the pilgrimage is focused on the completion of the journey and on the return home to one's familiar surroundings. Additionally, tourist activities may take predominance at this stage and pilgrims may engage in various local customs and behaviors. Because of the local economic impact of a pilgrimage site, there are often a variety of activities to be experienced by the pilgrim at the conclusion of the sacred journey (Davidson \& Gitlitz, 2002).

\section{Religious and Nonreligious Pilgrimage}

Pilgrimage is an important component in most of the world's religions and may exist to fill a religious void. This void may be understood through the exploration of specific historical and cultural meanings rather than a set of universal assumptions (Eade \& Sallnow, 1991) Until recently, the literature has reflected the religious nature of pilgrimages. However, with the increase in ease and frequency of travel, secular pilgrimages have emerged as a viable means of connecting deeply in an existential manner. Davidson and Gitlitz (2002) noted that a transition from purely religious pilgrimages to purely secular pilgrimages began to occur in the nineteenth century when American and Europeans traveled to places such a 
Niagara Falls and Yellowstone Park in order to connect with nature and because such places were "visible manifestations of deity" (p. 582). These authors also suggested that motives for secular pilgrimages include strengthening an individual's identity (such as traveling to an ancestral home) and engaging in some manner in a political journey (such as participating in a war grave pilgrimage to Gallipoli). More recently, spiritual tourism has emerged as new classification of travel. Spiritual tourism focuses on the spiritual quest of the individual that leads to transcendence or enlightenment and may be religious, secular, or a combination of both. It may or may not include religious affiliation, but often includes rituals, ceremonies, and traditions derived from different religions. Additionally, tourism statistics indicate that an increasing number of non-religious tourists are going on pilgrimages (Collins-Kreiner, 2009; Smith \& Puczkó, 2009). Notable pilgrimage scholars have observed that religious pilgrimages and secular pilgrimages share the characteristics of "ritual nature of the journey, the power of the special site, connection of the journey to powerful cultural myths, the social and spiritual connections established on the journey, and the transformative nature of the undertaking, including the transformation from illness to health" (Winkleman \& Dubisch, 2005, p. Xv).

\section{Personal Construct Theory}

That the phenomenon of pilgrimage ought to be explored through the framework of individual meaning-making is a contemporary notion (Courtney, 2013; Morinis, 1992). This meaning-making occurs as a result of an individual's prior experiences, beliefs, and personality. Substantive scholarship exists on a wide range of personality theories. (e.g., Erikson, 1968; Kohlberg, 1981; Piaget, 1936, 1963). Most of these theories are 
developmental in nature and examined the construct of personality in a stage manner that paralleled chronological development. George Kelly, a clinical psychologist, furthered the dialogue on the evolution of personality by an exploration of the idea that an individual evolves over time and that the individual is a scientist. His theory, personal construct theory, advocated that individuals view the world through patterns or templates or constructs. These constructs are tried on and evaluated and eventually retained if they contain predictive properties. If they fail to predict or lead to adaptation or meaning, they are rejected (Kelly, 1955). While the theory was developed as a framework for therapy, its concepts have been drawn upon for various empirical studies to include: self-image (Thomas, Butler, Hare, \& Green, 2011); assessment of student learning (Kreber, Castleden, Erfani, Lim, \& Wright, 2003); domestic abuse (Macrae \& Andrew, 2011); adolescent identity (Strachan \& Jones, 1982); and social action (Butt, 2011). Clearly, there are vast applications for personal construct theory and the placement of the individual within the greater meaning-making process has explanatory value for the study of pilgrimage.

\section{Assumptions}

Kelly cogently stated the assumptions of his theory. The first assumption is that the universe really exists and that humans are gradually evolving to understand it. Secondly, the existing universe is integral it that, "it functions as a single unit with all its imaginable parts having an exact relationship to each other" $(1955$, p. 6). A third key assumption of the theory is that "the universe can be measured along a dimension of time" (p. 7). Thus, the universe actually exists, it is interconnected, and it is moving all the time.

\section{Usefulness for Creating Meaning for Pilgrims}


Because the pilgrimage journey requires planning and a certain level of sacrifice, pilgrims are motivated to undertake the journey. They do so with the expectation that their current belief framework will be strengthened or that there will be some other biological, psychological, social, or spiritual benefit. Moreover, pilgrims carry with them prior constructs about the significance of the journey and of the specific pilgrimage site. For example, one scholar noted the following about Jerusalem's holiness, "What makes the city holy...is not something found in the city but, instead, something brought from outside and matched up there with monuments to, and markers of, sacredness" (Bowman, 1991, p. 98). Thus, as scientists, pilgrims begin their journey with a set of constructs about the meaning of the pilgrimage. Throughout the journey, and upon arrival at the sacred site, pilgrims either retain those constructs that had predictive value or reject those that did not align with reality. Additionally, some pilgrims only realize that journey is a pilgrimage after the event is underway or at the conclusion of the event (Winkleman \& Dubisch, 2005), indicating a change in construct.

Additionally, Kelly's notion that the universe is interrelated has relevance to the pilgrimage experience. The meaning constructed about the sacred site is present prior to the commencement of the journey. Thus, this meaning has been carried within the pilgrim's consciousness and/or external experience long before the physical connection with the site. For a Muslim pilgrim, it is likely that an awareness of the significance of the Hajj and the physical structure of the Ka'aba has been present since childhood. This type of pilgrim may have heard stories about the journeys of others in the community and may have received tokens of identification from the journey as a reminder of its importance. There is a high 
probability that the meaning construction of the Hajj has been connected to other symbols, events, and people in the pilgrim's life. Consequently, by the time of the pilgrimage, the platform exists for the experience to be a synthesis of multiple factors in one's life. Further, the actual experience connects the pilgrims from around the globe - these pilgrims share similar religious values, worldviews, and expectations of the actual pilgrimage journey and the sacred site.

Lastly related to personal construct theory, the pilgrimage journey occurs along the dimension of time. As mentioned above, pilgrims may anticipate the journey throughout an entire lifetime. This timeframe certainly does not exist for all pilgrims, but there is likely a linear timeline that occurs from the commitment to take the journey until the return home. Due to the complexity of the pilgrimage experience, it is plausible that pilgrims may not readily identify significant time points along the way. However, pilgrimage scholars have observed a series of consistent steps present in a myriad of pilgrimages. These include commitment to the journey, preparation, the actual travel or journey, preparation to enter the sacred site, the experience at the sacred site, completion of the journey, and the return home (Davidson \& Gitlitz, 2002). Consequently, for the current study, these time points will be explicated in order to fully analyze the therapeutic value of pilgrimage along the dimension of time.

\section{Usefulness for Interdisciplinary Approach to Pilgrimage}

In addition to the applicability of personal construct theory to the study of pilgrimage, Kelly recognized the value of exploring a particular phenomenon through the kaleidoscope of multiple academic disciplines. He asserted that, "There is no clear criterion by which a theory 
can be labeled 'psychological,' and not 'physiological' or 'sociological.' There is much interrelationship" (1955, p. 18). Thus, because of the complex nature of pilgrimage, it is appropriate to enhance the literature through the lenses of psychology and counseling as this is the particular "focal point" of inquiry (p.18). This focal point does not detract from the previous focal points within the domains of sociology, anthropology, and religious studies, but rather expands the understanding of pilgrimage as an individual phenomenon.

\section{Multicultural Counseling Theory}

A basic value of multiculturalism is the acceptance of the existence of multiple belief systems and multiple perspectives (Gonzalez, 1997). This value has resulted in the counseling profession's increased focus on multicultural issues within the counseling relationship and in the promotion of personal and professional development in this domain. Within the counseling relationship, counselors emphasize social constructionism and recognize that both the client and the counselor construct their worlds through social processes (Sue et al., 1998). Moreover, culturally competent counselors recognize their own cultural values and biases, develop an awareness of their clients' worldview, and utilize culturally appropriate intervention strategies (Arredondo et al., 1996). With regards to counselor personal and professional development in the realm of multicultural competence, counselors ought to: "commit to recognize the value of a client's cultural, ethnic, racial, socioeconomic, lifespan, and all other differences; strive to participate in firsthand social interactions with people from a variety of cultures; become familiar with the literature on multicultural counseling; use available assessment tools; and engage in critical reflection to identify harmful attitudes and behaviors that may compromise effective and competent 
counseling" (Baruth \& Manning, 2003, p. 76). The above values and competencies provide a general rationale for counselors and counselor educators to explore the pilgrimage phenomenon. Further, depending on the specific experience of clients, students, and counselors, there is a strong foundation for examination of specific pilgrimage sites and experiences.

In addition to the multicultural values and competencies mentioned previously, there is an increase in societal awareness about the role of spirituality in wellbeing and healing (Gallup \& Lindsey, 1999) and the recognition that wellness emerges from a balance between wellbeing in the body, the mind, and the spirit. The growing awareness and acceptance of the role of spirituality in well being and healing provides an additional context for an exploration of the significant function that pilgrimage exhibits in the lives of pilgrims. Moreover, the American Holistic Health Association (AHHA) (2012) indicates that there are two standard definitions of holistic that include a whole comprised of interdependent parts such as biological, psychological, social, and spiritual elements. Holistic is also used as a synonym for alternative therapies and these holistic and alternative therapies are gaining wider acceptance in the counseling field (Kottler, et.al, 2004).

\section{Pilgrimage and Multicultural Counseling}

Winkleman and Dubisch (2005) stated that there are cross-cultural similarities among pilgrimages. Because of the millions of people that engage in pilgrimage activity, many of whom are likely to be clients in a counseling relationship, a culturally competent counselor would benefit from learning about the basic elements of religious and secular pilgrimages. Additionally, the competent counselor would establish an ongoing inquiry into specific 
pilgrimage journeys as they relate to particular clients. For counselors who utilize a multicultural counseling paradigm, the connection between the spiritual dimension and the physical, psychological, and social dimensions is a critical component. In specific, nonWestern clients may rely on a "spiritual plane of existence in seeking a cure" (Sue \& Sue, 2008). And, even within the Western world, mental health professionals are beginning to recognize the role of spirituality in coping with identity issues, hopelessness, and feelings of powerlessness (Fukuyama \& Sevig, 1999). As such, a counselor may incorporate a client's pilgrimage journey into the counseling process as a therapeutic strategy.

To address ongoing self-development, a counselor may view a pilgrimage journey as an effective strategy for building multicultural competence. The immersion in another culture as well as the developmental process of the pilgrimage journey may likely result in an increase in self-awareness as well as in awareness of others. Moreover, a counselor may initiate a pilgrimage journey as a means of reconciliation, connection with others, or transformation.

\section{Chapter Summary}

Pilgrimage scholarship includes site-specific descriptions, analysis of structural change that results from the pilgrimage, and individual accounts of the significance of the journey. Within these individual accounts, some pilgrims have detailed various types of therapeutic benefits that include physical healing, spiritual connection, deepening of relationships with others, a desire to change society in a positive manner, and an increase in psychological well-being. These therapeutic benefits seem to occur as a result of both religious and secular pilgrimages and point to the pilgrimage process as being 
transformational and one that serves as the platform for significant meaning-making amongst all types of pilgrims. This meaning-making process can be explained through personal construct theory - the notion that individuals view the world through patterns, templates, or constructs. These constructs are retained if they are successful predictors of future events, behaviors, or perceptions and discarded if they lack predictive value. The notion that individuals construct meaning through social processes is the basis for multiculturalism and the establishment of multicultural counseling. Due to the substantial number of individuals that participate in pilgrimages, it would be beneficial for the cultural competent counselor to develop an ongoing repertoire of knowledge about various types of pilgrimage. Lastly, a counselor may benefit from his or her own pilgrimage journey to strengthen competence as well as engage in self-transformation. 


\section{CHAPTER THREE: METHOD}

Ten participants were interviewed about their pilgrimage experience. The interview format utilized was a semi-structured interview protocol. In addition, a constructivist grounded theory design was implemented to elucidate how pilgrimage is therapeutic.

\section{Role of the Researcher}

In a constructivist grounded theory research design, the researcher takes an active role in the research process. As stated by one grounded theorist, "In your role as an interviewer, your comments and questions help the research participant to articulate his or her intentions and meanings" (Charmaz, 2006, p. 26). Thus, in the current study, the researcher utilized the interview framework, but probed for meaning and clarification. In addition, the researcher engaged in a collaborative process with the participants to ensure accuracy in the transcripts and congruence between the emerging theory and the participants' experience.

\section{Research Design}

A constructivist grounded theory qualitative research design was used to explore the comprehensive meaning of the pilgrimage experience as well as the meaning of specific time points in the pilgrimage journey. As indicated by one prominent qualitative scholar, grounded theory has likely surpassed ethnography as the most commonly used qualitative research method (Morse, et al., 2009). This approach is appropriate for the current study due to the abstract analytical schema emerging about the pilgrimage phenomenon. Strauss and Corbin (1990) suggested that grounded theory is one that explains some action, interaction, or process and can occur through the collection of interview data. Further, McCaslin and Scott (2003) elucidated that grounded theory is an appropriate approach when the researcher 
is concerned with discovering a theory "for a single phenomenon of living as shared by others" (p. 450). It is rooted in symbolic interactionism, which stresses that people construct realities from the symbols around them and that individuals are active participants in creating meaning in situations (Morse \& Field, 1995).

Therefore, in this study, pilgrims, who were active participants in their own journeys, provided constructions of meaning about their experiences. In addition to the participants being actively involved in their own journeys, constructivist grounded theory is a specific method well-suited for the current study because there is a paucity of research on pilgrimage in the field of counseling, the current literature in other disciplines lacks the breadth and depth of the individual pilgrims' experiences, and a new point of view on the topic appears promising (Salkind, 2010). Moreover, this approach “celebrates firsthand knowledge of empirical worlds, takes a middle ground between postmodernism and positivism, and offers accessible methods for taking qualitative research into the $21^{\text {st }}$ century" (Charmaz, 2000, p. 510). The constructivist framework for the current study assumes a relativist epistemology, views knowledge as socially constructed, acknowledges multiple standpoints of both the research participants and the grounded theorist, and takes a reflexive stance towards actions, situations, and participants (Charmaz, 2000, 2006).

\section{Participants}

Consistent with qualitative research protocols, a purposeful sampling approach was utilized in order to "permit inquiry into and understanding of a phenomenon in depth" (Patton, 2002, p. 46). Participants were selected based upon email, phone and face-to-face screenings that confirmed that they classified their journey as a pilgrimage and that the 
pilgrimage was within the past two years. Because a grounded theory approach is based on the emergent data, the sample is not well defined prior to beginning the data collection process (Ezzy, 2002). This sampling method, called theoretical sampling, ends when the researcher has decided that the study has reached saturation. Saturation occurs when there are no new ideas of themes that emerge from the data (Glaser \& Strauss, 1967).

Participants were recruited through a variety of religious institutions (i.e., Islamic mosques, Christian churches, Jewish synagogues, and Hindu temples in the Raleigh, NC area), via email requests, and through announcements in weekly or monthly newsletters or bulletins. In addition, participants were recruited through email and face-to-face contact through veterans' organizations in Raleigh, NC and Boise, ID. Moreover, participants volunteered for the study based on hearing about the study from the researcher and from other participants. After the initial screening and selection outlined above, an interview time was scheduled either at the participant's home or at a mutually agreed upon location. The informed consent and interview questions were emailed or mailed to the participant for review prior to the interview. Each participant either chose or was assigned a pseudonym by the researcher to maintain confidentiality. In addition, identifiers such as organization names and personal names were altered in the transcript to ensure the confidentiality of others discussed by the participant. Participants were also informed that they had an opportunity to win a Visa card worth twenty-five dollars in a randomized drawing. This drawing occurred at the conclusion of the interview process. As part of the data collection, participants reported the following demographic information: age range; ethnicity; gender; highest education completed; religion; and ways religion and/or spirituality are practiced. 


\section{Said}

The first male participant, Said, went on the Islamic Hajj pilgrimage. He reported his age as 55-59 years old, listed his ethnicity as White, and reported his highest education completed was a doctoral degree. He stated that his religion was Islam and that he practiced his religion by "praying, fasting, and treatment of others."

\section{Frida}

The second participant was a White female. Frida reported her age as 55-59 years old and stated that her highest level of completed education was a doctoral degree as well as rabbinic ordination. In addition, she reported that her religion was Judaism and that she practiced her religion through "personal practice and spiritual leadership in a synagogue." She participated in a pilgrimage to the Czech Republic during which sites important to the Jewish community were visited. These sites included contemporary Jewish sites as well as World War Two era places related to the Holocaust.

\section{Seth}

The third participant, Seth, was also a part of the pilgrimage to the Czech Republic and reported his age as $75+$ years old as well as categorized himself as a White male. He stated that his highest education level was a doctoral degree and his religion was Judaism. With regards to the practice of his religion. Seth stated, "I pray part of the liturgy twice a day, observe the Sabbath, offer prayers for healing, and observe the holidays."

\section{Christine}

The fourth participant was a White female named Christine who participated in an identity development pilgrimage to her family's ancestral homeland of Ireland. She reported 
her age range as 30-34 years old. In addition, Christine stated that her highest level of education was a master's degree and that her religion was Catholic. She reported that she practiced her religion and/or spirituality "through family celebrations and personal development. I do not attend church regularly, but try to incorporate spiritual practices/meditation/prayer into my daily life."

\section{Ashanti}

The fifth participant, Ashanti, also participated in a pilgrimage related to identity when she traveled to West Ghana. Ashanti reported her age range as 30-34 years old and her ethnicity as African-American. She had completed a master's degree and stated that her religion is Christian. About her religious/spiritual practice, Ashanti, stated, "I attend church services several times a week. I pray daily and read the bible through meditation.”

\section{Mike}

The sixth participant, Mike, was a 35-39 year old White male who had completed a master's degree. Mike went on a pilgrimage to a monastery in the southeastern United States. He reported that he was Christian and practiced his religion/spirituality through "worship services and reading."

\section{Avila}

The seventh participant, Avila, was a White woman aged 35-39 years old. She had completed a master's degree and reported her religion as Christian. She stated that she practiced her religion/spirituality in the following ways: "attend church; donate money to church and charities; daily prayer; daily Bible reading; awareness of social justice issues; and effort to maintain harmonious relationships with others." Avila went on a pilgrimage journey 
to a Catholic retreat center in North Carolina.

\begin{abstract}
Alcuin
The eighth participant, Alcuin, participated in a pilgrimage to Chimayo in northern New Mexico. He stated that he is a White man, aged 55-59 years old. He has completed a doctoral degree and classified his religion as Christian/Presbyterian Church USA. He disclosed that he practices his religion/spirituality in the following ways: "attend worship weekly, if not twice a week; go on an annual spirituality retreat; lead pilgrimages here and abroad; prayers, using Benedictine prayer book, daily in the morning and evening."
\end{abstract}

\title{
Wild Bill
}

The ninth participant, Wild Bill, was a Vietnam veteran who rode on the motorcycle pilgrimage to the Vietnam Wall. Wild Bill reported that he was a White man, aged 65-69 years old, and had completed a master's degree. He categorized his religion as Christian - not affiliated with any organized religion. About his religious or spiritual practices, Wild Bill stated, "I pray daily and study the Bible; I use time spent in solitude in the mountains and river valleys of the northwest as a form of worship; and I believe that organized religions are more about controlling members than about worshipping God."

\section{Bull}

The tenth participant, Bull, was a White man aged 75+ years old. His highest education completed was some college and his religion was Catholic. Bull stated that he practiced his religion through "weekly mass." This participant was a World War II veteran and made a pilgrimage to the military memorials in Washington D.C. as part of the national Honor Flight program. 


\section{Investigator Bias}

Corbin and Strauss (2008) asserted that interviewers bring to research biases, beliefs, and assumptions; however, this is not necessarily a negative happening. These authors suggested that important meaning making can occur because of shared experiences between the interviewer and the interviewee. The key is for the interviewer to "walk a fine line between getting into the hearts and minds of the respondents, while at the same time keeping enough distance to be able to think clearly and analytically about what is being said or done" (pp. 80-81).

An interest in the topic of pilgrimage occurred while preparing for a study abroad trip to Israel in 2010 in which literature about the country addressed the importance of pilgrimage in the broader culture of the Middle East. During the actual visit to Israel, hundreds of different types of individuals participating in pilgrimage journeys to religious, military, and political sites were observed. Without exception, the individual pilgrims seemed deeply engaged and appeared to be in the midst of a transformational experience. Upon further reflection, a significant developmental experience during a visit to the Vietnam Wall at the age of fourteen was recalled. These two experiences, along with other meaningful sacred travel journeys, influenced thoughts about the therapeutic value of pilgrimages. In addition, a thorough review of the literature on pilgrimage led to considering that it appears evident from the observations of previous scholars, as well as from the narratives of pilgrims, that pilgrimage experiences are transformational in a number of ways that could be construed as therapeutic. Thus, this led to a strong belief (bias) that pilgrimage is a therapeutic endeavor. 


\section{Instrumentation}

As previously noted, substantial amounts of empirical data on the topic of pilgrimage have emerged through the published ethnographies of anthropologists (Bowman, 1993; Dubisch, 2005; Gilmore, 2005; McKevitt, 1991; Turner, 1969). Because of the nature of the pilgrimage experiences outlined in previous scholarship, ethnographic research methods were appropriate for anthropological inquiry. However, the goal of the current study was to explore pilgrimage through the lens of counseling and psychology. Consequently, the qualitative interview is a valid method, within the disciplines of counseling and psychology, that may be used to gather in-depth, substantive data from a participant about a particular phenomenon. As such, retrospective semi-structured interviews (Corbin \& Strauss, 2008) were used to explore the experiences of multiple pilgrims and provided the opportunity for these pilgrims to describe the meaning assigned to their experiences. Retrospective interviews are an interview format that explores events that have occurred in the past. Participants speak about these past experiences as well as the perspective that has been gained during the time from the end of the event to the present. The therapeutic value of the pilgrimage experience, as defined by the pilgrims, will help inform future research about this phenomenon and will provide counselors insights about possible interventions. According to scholars in the field, qualitative interviews are considered the backbone of qualitative research and evaluation (Charmaz, 2006; Corbin \& Strauss, 2008; Morse, 2009). Unlike surveys, which consist of carefully worded, closed-ended questions, qualitative interviews are one-on-one, interactive conversations between an interviewer and an interviewee. The objective of qualitative interviews is to obtain rich, detailed information in the form of 
narratives or stories of people's experiences. The data that are derived from qualitative interviews explain and give meaning to people's lives. Thus, it is critical that the interview contains sound questions that enhance the discovery of new knowledge (Corbin \& Strauss, 2008). Interviewers work from a script of questions that can contain prompts that support limited flexibility.

Because of the research design of the current study, the experiences of the pilgrims were extrapolated through the use of open-ended interview questions. Since the researcher and the participant did not experience the journey together, the purpose of the questions was to elicit specific memories and meaning assigned to time points along the pilgrimage journey. The time points are those that have been addressed as steps in the pilgrimage process.

\section{Interview Question Development}

The following section outlines the development of items used for the interview protocol. The interview questions were developed in response to previous literature (e.g., Davidson \& Gitlitz, 2002; Eade \& Sallnow, 1991; Gopal \& Dubey, 1990; Morinis, 1992; Smith \& Puczkó, 2009; Winkleman \& Dubisch, 2005) on the topic and are focused on the development of a grounded theory framework for understanding the therapeutic value of pilgrimage. The interview items and demographic questions are located in Appendix A.

Questions 1 and 2. What motivated you to go on a pilgrimage? and What did you hope would happen during your pilgrimage? These questions addressed motivations and expectations about the pilgrimage journey and are based on the conclusions of scholars that pilgrims undertake the journey for multiple reasons to include religious obligations, search 
for identity, and desire for connection with the divine (Davidson \& Gitlitz, 2002; Eade \& Sallnow, 1991; Gopal \& Dubey, 1990; Morinis, 1992; Winkleman \& Dubisch, 2005).

Question 3. What made your journey a pilgrimage? This item addressed the definition of pilgrimage. Scholars have recognized that pilgrims define a pilgrimage in a variety ways (Eade \& Sallnow, 1991).

Question 4. Would you classify your pilgrimage as religious or secular or both? and What about your pilgrimage made this the case? This item addressed the notion that pilgrimages may be religious, secular, or a combination of both. Scholars in the field have noted these categorizations (Collins-Kreiner, 2009; Davidson \& Gitlitz, 2002; Eade \& Sallnow, 1991; Smith \& Puczkó, 2009; Winkleman \& Dubisch, 2005;).

Question 5. Did you go on your pilgrimage alone or with others? What influenced your decision for this? This addressed the notion of communitas written about by V. Turner (1969) as well as the contestation of this idea by Eade and Sallnow (1991).

Question 6. Describe your overall pilgrimage experience. This item explored the overall pilgrimage experience and provided the participant with the opportunity to speak of the experience in its entirety and as more than the sum of any one part (McKevitt, 1991; Pace, 1989; Turner, 1969; Turner, 1974; Turner \& Turner, 1978; Winkelman \& Dubisch, 2005).

Questions 7-14. These interview items that specifically framed the individual time points along the journey within a therapeutic context guided the participant to recall the therapeutic value of each time point. The specific language utilized in the questions was based on the construct of therapeutic value (Kelly, 1955) and relied on the pilgrimage steps 
as outlined by Davidson and Gitlitz (2002). Each item inquired about the following time points along the pilgrimage journey: (a) initial commitment; (b) preparation for the pilgrimage journey; (c) actual pilgrimage journey; (d) preparation to enter the pilgrimage site; (e) experience at the pilgrimage site; (f) departure from the pilgrimage site; and (g) return home. These items also asked the question In what way was the experience therapeutic for you?

Question 15. Is there anything else about your pilgrimage experience that you would like to share with me? This item provided the opportunity for participants to offer additional information about their experience according to their personal construct about pilgrimage (Kelly, 1955). Additionally, the earlier questions may not have led to a full extrapolation of meaning due to cultural differences between the researcher and the participant; however multiple belief systems and multiple perspectives are embraced (Gonzalez, 1997).

\section{Procedure}

Prior to the beginning of the study, approval was obtained by the Institutional Review Board (IRB) at North Carolina State University (See Appendix B). After the participants were initially screened for an appropriate match for the current study, they were contacted to arrange the interview. The interviews were done face-to-face at locations mutually agreed upon by the participants and the researcher. The average length of the interview was one hour with rapport building conversation prior to the interview as well as discussion after the interview. This discussion included additional details about the pilgrimage destinations and participant questions about other pilgrimages profiled in the current study. The recorded interviews were transcribed and a detailed coding process was implemented. The codes were 
analyzed for themes and a constructivist grounded theory was proposed based on interpretation of the data.

\section{Data Collection}

As previously stated, the participants were interviewed in a face-to-face protocol format in a location agreed upon by the researcher and the participants. Locations included conference rooms, homes, and professional offices. The locations were quiet spaces in which the only people present in the immediate area were the investigator and the participant. In two of the interviews, the participants asked if their spouses could be a part of the interview and informed consent was also obtained from the spouses. The participants were contacted by telephone or email to confirm the interview time and place. Congruent with literature on semi-structured interviews, the researcher conveyed to the participants a genuine interest in their pilgrimage experience, a desire to establish a comfortable rapport, and flexibility in scheduling the appointment time and place (Salkind, 2010). Participants were emailed or mailed the informed consent and interview items prior to the scheduled interviews in order to promote a collaborative rapport. Additionally, participants were encouraged to bring to the interview pictures and other artifacts from the pilgrimage journey to share with the researcher. At the beginning of the interview, and prior to turning on the audio recorder, the informed consent document was reviewed and signed by both the researcher and the participant. Further, the researcher explained her interest in the topic of pilgrimage and asked if the participant had questions or needed clarification about the study. Once the participant signed the informed consent and all questions were answered, the interviews were audio recorded with a digital recorder. The recorded interview audio files were stored on a 
password protected and encrypted computer storage device. The interviews were electronically shared with a professional transcriber via a secure and password protected filesharing site. Interviews were transcribed verbatim and the line-by-line transcripts were shared with the researcher via the electronic file-sharing site. The researcher reviewed each interview transcript by listening to the audio file while simultaneously reading the transcript to ensure verbatim accuracy. The transcripts were altered if they contained specific names of people or organizations in order to protect the participant's identity and the identities of other individuals mentioned during the interview. The transcript was then emailed or delivered to the participant for review and emailed back to the researcher (or picked up by the researcher) upon successful verification. The original audio files were permanently deleted and the transcripts were saved on a password protected and encrypted computer storage device.

\section{Data Analysis}

The semi-structured interview framework and a constructivist grounded theory perspective that emphasizes the respondents' lived experiences, stories, and meaningmaking informed the analysis in the current study (Denzin, 1988; Prus, 1995). The general analytic steps were: (a) examination of the interview transcripts for general statements about the motivations for the pilgrimage journey and specific statements about the therapeutic value of individuals time points along the journey; (b) development of themes around these topics; (c) construction of analytic categories from the themes; and (d) linkage to the previously identified analytic categories into a coherent process (Charmaz, 2009).

Coding. Coding provides the opportunity for the researcher to begin to name "segments of data with a label that simultaneously categorizes, summarizes, and accounts for 
each piece of data" (Charmaz, 2006, p. 43). Consistent with a grounded theory approach, there are two primary phases of coding. The initial phase involves naming each word, line, or segment followed by a focused, selective phase the uses the most significant or frequent codes to, "sort, synthesize, integrate, and organize large amounts of data" (Charmaz, 2006, p. 46). A stepwise process was utilized for coding data: (a) initial coding; (b) focused coding; (c) axial coding; and (d) theoretical coding.

Interview transcripts were transcribed and coded by independent coders. Based on the conclusion of a prominent grounded theorist that, "outsiders often import an alien professional language to describe the phenomenon" (Charmaz, 2006, p. 49), the coders only included those in the researcher's field. In specific, the coders were the researcher and two other counselor education doctoral students. All coders had taken a qualitative research class and were familiar with grounded theory. The coders were recruited based on their personal relationship with the investigator and had worked as a team on previous projects in the doctoral program. The researcher trained the coding team through a formal presentation and discussion about the stepwise process of the development of a grounded theory which was based on the manual by Charmaz (2006). The coding team was given a written overview of the process as well as examples that illustrated each step. Published transcripts and codes from the Charmaz manual were also discussed to ensure all coders viewed the data from a similar perspective. The coding team worked through the coding process together for the first transcript. The steps of this process included the coding steps mentioned above and specific coding examples are profiled below. 
Initial coding. This step within the coding framework consists of code assignments that stick closely to the data and reflect action rather than feeling. Initial codes are provisional and remain open to future analysis. Initially, line-by-line coding was utilized, which is the process of naming each line of the written data (Glaser, 1978). The coding team independently read through the transcript and assigned initial codes to each line of the transcript. These initial codes were based on the actions of each segment. Examples of these codes are connecting to heritage and experiencing acceptance.

Focused coding. This second phase in the coding process is characterized by a synthesis of larger segments of data. This step is initiated after strong analytic directions have been established (Charmaz, 2006). For example, the above initial codes were subsumed under the focused code connecting to legacy and family heritage.

Axial coding. Strauss and Corbin (1998) suggested that axial coding is a strategy for bringing the data back together into a coherent whole. Axial coding, "relates categories to subcategories, specifies the properties and dimensions of a category, and reassembles the data you have fractured during initial coding to give coherence to the emerging analysis" (Charmaz, 2006, p. 60). The axial code homecoming incorporated the previous initial and focused codes.

Theoretical coding. Theoretical codes specify possible relationships between categories developed during the earlier coding processes. These codes are integrative and move the analysis in a theoretical direction (Charmaz, 2006). For the current study, a theoretical code emerged as one in which therapeutic value, across the sample, seemed to be defined or clustered in a particular way such as a social domain (Turner, 1969). In specific, 
the axial code homecoming was encompassed under the theoretical code of social therapeutic value.

Memo-writing. Memo-writing is central to grounded theory as it forms the foundational structure of the emerging coding theme (Ezzy, 2002). It also prompts the researcher to analyze the data and codes early in the research process (Charmaz, 2006). The memo-writing process includes taking notes on thoughts, comparisons and connections in the data, possible theoretical directions, and directions for future pursuit. After each interview, the investigator utilized memo-writing to document initial thoughts and perceptions about the data. For example, after the first two interviews, the investigator noted a difference in meaning construction regarding the same pilgrimage event. The two participants had gone on the same pilgrimage and recounted the same event, but each assigned a different meaning to the event, which is consistent with Kelly's personal construct theory (1955). Moreover, the memo-writing led to additional questions for future participants. The primary example of this is that the initial participants mentioned the significance of a communal meal during the pilgrimage and the investigator incorporated this knowledge into future interviews by asking the participants about it. This, the grounded theory was constructed during the data collection process (Charmaz, 2006).

\section{Data Interpretation}

Congruent with a grounded theory approach, after the data have been collected and the themes analyzed, an interpretive process continues with the emergence of the grounded theory (Charmaz, 2006). Consistent with the focus on an individual pilgrim's construction of meaning about the lived pilgrimage experience, a constructivist approach was used to 
interpret the emergent theoretical constructs. In a constructivist grounded theory framework, the participants interpret their own experiences as well as embrace the notion that the resulting theory is an interpretation (Bryant, 2002). Thus, a parallel process transpires in which the researcher and the participant utilize personal constructs (Kelly, 1955) in the interpretive analysis. The constructivist grounded theory approach is also congruent with the multicultural counseling paradigm because social constructivism is viewed as a significant value and there is recognition that both the client/participant and the counselor/researcher construct their worlds through social processes (Sue et al., 1998).

\section{Establishing Trustworthiness}

Since standards of reliability and validity are not applicable to the grounded theory paradigm, the theory was assessed by four standards referred to as fit, work, grab, and modifiability (Milliken, 2010). Fit is ensured when themes and categories are generated from the data rather than from preconceived constructs (Morse \& Singleton, 2011). A specific way that fit was demonstrated in the current study was through the use of verbatim quotations from the participants. A second standard used to establish trustworthiness is work. This construct refers to the notion that a theory, "should explain what happened, and variation in how it happened, predict what will happen, and/or interpret what is happening for the people in the setting" (Milliken, 2010, p. 552). For the current study, participants reviewed their transcripts for accuracy as well as reviewed the emerging grounded theory for congruence with their experience. A third standard for the establishment of trustworthiness is grab, which refers to the degree the theory is relevant and recognizable to participants and others in similar characteristics (Milliken, 2010). Further, the researcher or participant "feels like he or 
she can explain what they see" (Glaser, 2002, p. 16). For the current study, participants and pilgrimage researchers were asked to review the emergent theory about the therapeutic value of pilgrimage. In specific, feedback about the theory's relevance and recognizability were requested. The fourth step to establish trustworthiness in grounded theory is modifiability. The importance of this step emerges after the theory has been completed and applied (Milliken, 2010). Because of the evolutionary characteristic of this step, it was not established in the current study. However, future research related to the identified grounded theory will consider the modifiability of the original theory. 


\section{CHAPTER FOUR: RESULTS}

Because the study utilized a constructivist grounded theory approach through the use of a semi-structured interview framework, there were two levels of analysis. The first level of analysis provided data for each interview question and provided an overview of the participants' responses. The second level of analysis constructed the grounded theory through the establishment of initial, focused, axial, and theoretical codes. This construction was based on the participants' collective experiences and is an aggregate of the entire sample.

\section{Analysis of Interview Items}

Each item from the semi-structured interview protocol was analyzed and examples of participant responses are detailed below. This analysis provided a contextual structure from which to develop the thematic analysis of the grounded theory. Further, these questions were the launch point for additional questions as the study evolved.

\section{What Motivated You To Go On a Pilgrimage?}

With regards to motivation for the pilgrimage, all of the participants reported that it was one step in a broader process. There were typically years of planning, previous connections to the pilgrimage site or people, and events or conversations with others that led to the final decision to embark on the pilgrimage journey. For Wild Bill, who was a Vietnam veteran and motorcycle enthusiast, knowledge about Run for the Wall emerged from relationships with others. He stated, "I think as I built, started to just reconnect a little bit with people that had similar experiences in Vietnam...the guy that was my roommate when I first moved back here (after I got out of the military) came to visit me and they told me about this thing that they were working on Run to the Wall. Now this would've been, oh, I'd have 
to look at the history... I mean, these two guys were early movers in this whole idea of putting motorcycle rides together throughout the United States and going back to the Wall and trying to do something about MIAs, people that had not been located in Vietnam. You know, at that point, I just thought, 'Wow. That would be something that I would really like to get involved in."”

For the study participants, the pilgrimage journey was not an isolated phenomenon and was an intentional endeavor based upon prior meaningful engagement. For Ashanti, the death of her mother precipitated the pilgrimage along with conversations with previous pilgrims who had experienced something transformational. Another pilgrim, Avila, was experiencing post-partum depression and "knew that pilgrimage was a good experience for me."

For Christine, who identified herself as ethnically Irish, yet disconnected from her heritage, the pilgrimage was based on a realization that "in order to be the best counselor I could be, I really needed to get in touch with my people and my roots." For Said, a Muslim participant, the decision to go on the Hajj was a result of hearing his friends describe their experiences and "how it really transformed you."

\section{What Did You Hope Would Happen During Your Pilgrimage?}

The participants in this study had a variety of expectations regarding their pilgrimages. For Alcuin, who journeyed to Chimayo, there was an expectation that the pilgrimage would lead to a testing of the body, mind, and spirit. Seth, who went to the Cezch Republic, hoped "that the graciousness of the people that we had experienced on the first trip would be repeated - that it wasn't a one-time thing. When I go to Europe - and probably 
when most Jews go back to Europe who are around my age - you can't make that trip without thinking of the Second World War and the Holocaust. So it's very heavy baggage going back. I lost a lot of family in the Second World War, and even though I was a little kid, I knew about it and it was part of the family history. So, my feelings towards the Czech people were going to be, to some degree, shaped by these experiences."

Ashanti, who was dealing with the grief from her mother's death, stated that, "my goal... is that I began to see life differently." Most pilgrims addressed some type of hope for connection with others, within themselves, with the land, or with the larger community.

\section{What Made Your Journey a Pilgrimage?}

With regards to what characterized the particular journey as a pilgrimage, Mike stated, "It's not my normal environment. It's not my normal surroundings... and it seems, a place closer to God." Alcuin addressed that the journey was a pilgrimage because of its "intentionality" and Said classified his journey as a pilgrimage because it was a journey that "really moved me and left an everlasting effect on me."

For Christine, "It was a pilgrimage for me because it was a journey of self-discovery and a journey of identity in a way that was stronger than, you know, kind of Eat, Pray, Love because in that book she didn't go to a place that was significant to her. For me, this was a significant site. It was a site in a town that I had heard about my whole life."

Related to the significance of the site, there is also an indescribable sense by many pilgrims that they feel drawn to the journey. Wild Bill stated, "The Run to the Wall was a pilgrimage that I had wanted since I first heard the concept and I really can't tell you why. I don't know why it was so important to me, but I knew it was." 
Further, there is a type of connection to the physical place as evidenced by Seth's assertion, "In the sense of going to some place to which people of my religion had lived and had this horrible, painful experience." For Bull, a World War II veteran, his pilgrimage to the memorials in Washington D.C., and specifically Arlington National Cemetery, was a significant event in his life's journey. He stated, “That's one of the great highlights of my life, being able to lay a wreath to the tomb of the unknown soldier."

\section{Would You Classify Your Pilgrimage As Religious Or Secular Or Both? What About Your Pilgrimage Made This The Case?}

Answers regarding the religious or secular nature of the pilgrimage varied. For some, there was an overtly religious motivation for the pilgrimage. Alcuin stated his pilgrimage was religious because, "When you begin in the morning, every morning you begin with thirty minutes or an hour of prayer because you leave at five o'clock in the morning because you don't want to wake the rest of the town up. That's followed by an hour of doing the rosary or singing songs, then an hour of conversation; but there's always the sense because you're carrying the cross, you're carrying a plaque with the image, the icon of Our Lady of Guadalupe. You're constantly aware of that this is a religious trek; this is a religious journey. There's never been a time on this specific journey that you were given a break from any kind of religious ideation." For others, the pilgrimage was both religious and secular.

Ashanti stated, "Well, I would classify, to me, as religious and secular meaning the history part, knowing about the history of Africa because I didn't know. Like, I mean, people told - I mean, you know, I'm black and so they told me I'm from Africa, but how can... I mean, I don't really know what, I've never been over there. So for me it was a religious point 
and then it was also knowing about my culture and knowing about my race and knowing where that foundation came from."

For Christine, her pilgrimage to Ireland became religious in an unexpected way. She reported, “It's interesting because I am definitely a lapsed Catholic. I don't really agree with a lot of the policies and the kind of thing - the way the Catholic church is going I'm not the biggest fan of, but I found myself more interested, connected and present - I actually went to church at least three times while I was there which was shocking because I never go to church at home and I have not gone to church since I've been back, but I actually sat next to a priest on the plane - like, it was just weird stuff kept happening that kept making me feel drawn into kind of a greater sense of being and a greater sense of purpose. And I feel more spiritually awake than I have in the past."

\section{Did You Go On Your Pilgrimage Alone Or With Others? What Influenced Your}

\section{Decision For This?}

All of the participants in this study went on pilgrimages with others. For Seth, his decision to go on the pilgrimage with others was related to the fact that he was part of a group that traveled together. He stated, "It was also the fact that my wife was now leading that group so that was also definite motivation. You know, I was going to join her on that trip."

For Mike, the decision seemed more about practical considerations. He reported, "It was basically - the times I've been on pilgrimage I've gotten a lot out of it, I felt like. Like, I felt like it was a good experience for me. And so if I was going to drive six hours down to Georgia, then if I've got open space in the car, then someone else could come with me." 


\section{Describe Your Overall Pilgrimage Experience.}

Participants described their entire experiences in a meaningful narrative. The components of the pilgrimage narratives are detailed in the following sections.

Please describe how you made an initial commitment to your pilgrimage journey. In what way was your initial commitment to the pilgrimage journey

therapeutic for you? The initial commitment to the pilgrimage journey was recalled by most participants as being the event in which precise dates were identified for the journey and when a financial deposit was made for the journey. Said stated, "I would say for about, like, at least five to six years it was kind of hesitant; go this year, wait for next year...there was one year like two years ago where actually it kind of lined up exactly with Thanksgiving holiday. So, about the year before - I made my intentions, 'I'm going to go this year.' And I put a deposit and that was it because I could do it over the Thanksgiving holiday because you always have to balance work and personal life."

With regards to making an initial commitment, the participants shared that this commitment was therapeutic primarily because of the anticipatory excitement. Mike stated, "It gave me something to look forward to. Like, it gave me something tangible to like, you know, anchor, I guess. You know, it was like an anchor in time for me, right? You know, it's like, 'I've got to work three weeks before I get to go on my pilgrimage. I've got to work two weeks before I go on my pilgrimage.' And it's a week, like, it's probably the only thing that I ever do in my life where, that I don't have any stress about."

Ashanti stated about committing to the pilgrimage, "It gave me huge relief because I had been rolling like roller skates. And mind you, you know, your expectation is to keep 
everything up. You know, I went back to work a week after my mother died and stayed there until the end of July - end of June - so I really only had one month to really be by myself and then I jumped right back to it in August."

\section{Please describe how you prepared for your pilgrimage journey. In what way was} the preparation for your pilgrimage therapeutic for you? The preparations for the pilgrimage journeys included arranging for time away from work, shopping for items related to the journey such as clothing and sleeping gear, and reading books about the pilgrimage process or destination. For Said, preparation included structured classes related to the Hajj. He reported, "I went through all the educational sessions with the tour guide and I also attended some educational sessions here in IAR [Islamic Association of Raleigh]."

Alcuin stated, "I think it's also helpful you always take a twenty mile walk before you actually do the pilgrimage itself. It is important to go ahead and exercise before you actually do the pilgrimage because that will tell you whether your body is up to it or not and you'll be able to figure that out. So most of us do a twenty mile test run before we actually go on the pilgrimage itself because there's a good chance that we may or may not make it; there's no guarantee that once you've been on this journey that you will make it. If you are seen as lagging behind and unable to keep up with the group they will ask you to leave the pilgrimage so it's pretty hardcore."

The preparatory acts were therapeutic for many reasons. Ashanti shared, "It felt therapeutic shopping for things I never would have thought of...doing something for the first time in your thirty-two years of life that you wanted to do." Another preparatory act included building a motorcycle for the Run to the Wall. Wild Bill stated, "So it really was very much a 
commemorative bike that I built just specifically to take on this ride and I didn't plan on it meaning anything to anybody else, I just knew what it meant to me, you know, the symbolism."

Please describe your actual pilgrimage journey. In what way was the actual pilgrimage journey therapeutic for you? Participants described their pilgrimage journeys primarily in chronological order. Many of them utilized photographs of their journeys and shared meaningful stories as they displayed the photos. Ashanti reported that the pilgrimage was therapeutic because of "waking up in the morning and having fresh air" and Said stated he had a "comforting feeling" while on the pilgrimage.

Frida stated, "It feels tremendously rich and feels like doing a right thing, and it energizes me for the routine. So it provides a spectacular interlude of being entangled in something that feels important in some ineffable way."

Alcuin asserted, “It re-centers one's life. It is, as one who has written and spoken out on how life is journey, life is a pilgrimage, we are pilgrims in a community of faith, that the body of Christ itself is on a pilgrimage on this earth, I think the actual intentional pilgrimage provides a time of recalibration so that I'm actually, my body is actually reminded and tweaked to and given the experience of a journey so that I know that I am, in life, metaphorically and figuratively and literally on an ongoing process of journeying."

Please describe the experience of entering the pilgrimage site in your pilgrimage journey. In what way was the experience of entering the pilgrimage site in your pilgrimage therapeutic for you? For Said, there was a particularly meaningful ritual called the Sai, during which pilgrims recreate the acts of Hagar running between the mountains, 
Safah and Marwah, to find water for her son, Ishmael. Said stated, "During the Sai, it was more thinking we're repeating what Hagar did which is... was really, very, thinking about how she did it and, you know, all that it's very moving for me." Also, during the Hajj pilgrimage millions of people circle that Ka'aba and Said remarked, "That's the only time, actually, the only place where women will pray next to men; front, back, it doesn't make any - wherever you happen to be, just stop, you line up and you pray."

Please describe the experience of preparing to enter the pilgrimage site on your pilgrimage journey. In what way was preparing to enter the pilgrimage site on your pilgrimage therapeutic for you? For many pilgrims, there is a separate experience of entering a site and then making specific preparation for touching a shrine, praying, etc. In the current study, this was not applicable for any of the pilgrims.

Please describe the experience of being at the pilgrimage site on your pilgrimage journey. In what way was the experience of being at the pilgrimage site on your pilgrimage therapeutic for? Christine visited a church in Ireland in which significant life events in her family had occurred. These events included baptisms, marriages, etc. For her, the holy water in the church was meaningful. She said, "You know, they have the little holy water and so I remember doing, crossing myself with holy water and just feeling - and I feel like this in a lot of churches, but, well, I felt like that in a lot of churches in Ireland, but not when I was here. Whenever I see holy water, it's somewhat superstitious or something, I always go over and get some because I'm like it can help somehow. So having that water on me though was just like the water from home, the water from... you know, just that rebirth kind of thing. That really was significant as far as I've blessed myself with holy water 
thousands of times throughout my life, but this water was significant because it was the water of my people."

For Ashanti, "The castle stood out because I told you how I was able to relate to a castle being my struggle, not just holding the slaves there. I'm not talking about - I'm talking about life. But there was one part, we went to the Ashanti region and we made, we went to a part called City Beads and we made beads there, but that part was very touching for me because that was the region where the Ashantis would not give up the stool. There was a chief's stool that the British wanted from the Ashantis and they would not give it up. So they went to war over a stool - yes, over a stool - but that signified power for them."

Seth recounted the visit to Terezín, or Theresienstadt, in the northern part of the Czech Republic. He stated, "And there we had an absolutely amazing experience, which most of us felt, 'Yes!' Yes, this was quite amazing - I mean we were visited by two angels, and we knew it." Frida stated about Terezín, "So, I think there was a healing that happened in that place and it's nothing that I take credit for, and it wasn't a direct intention, but I think it's a by-product of arriving with an intentionality to do something to shift the relationship between people who could only feel themselves to be enemies."

Please describe the experience of leaving the pilgrimage site in your pilgrimage journey. In what way was the experience of leaving the pilgrimage site on your pilgrimage therapeutic for you? Since many of the pilgrimage journeys included many sites, the responses to this question were varied and included the collective pilgrimage experience. Said stated, "You kind of, you feel that you fulfilled one of your duties. You feel satisfied. You feel that, you are really ready to come home. You feel, it's almost like what 
they say, like recharge your batteries, you know? It's... you need to come back home and start life again, uh, think about to say to yourself, 'I'll be more disciplined this time.' Afterwards, more terms of like praying on time or being nice to people, what have you. You kind of, you make a commitment to yourself that you'll be a better person from now on."

Please describe the experience of returning home after your pilgrimage journey.

\section{In what way was the experience of returning home after your pilgrimage therapeutic}

for you? Most participants described the experience of leaving as bittersweet. Mike stated, "I would say it was mixed emotions. You know, there's a certain excitement about, 'hey, I haven't seen my family in a week and I'm looking forward to seeing my family.' There's a certain sadness that you have to go back to the world, I guess, and back to all the busyness and distraction. There's also a certain relief actually. It can be very jarring to live in all the busyness with all the background noise all the time, then going into something of relative silence for a week. And it's like you almost, you almost confront things, like, on a spiritual or emotional or intellectual level that are so real that you just want to retreat from that and go back to the busyness and go back to the background noise. So there's a certain relief to leaving just because it's like, 'Yeah, okay, I didn't know that about me and I don't want to deal with it' kind of thing. So, yeah, so I would say it's definitely mixed emotions, like you almost don't even know how to process it really."

Alcuin echoed Mike's sentiment and stated, "Bittersweet. The bitter part is no one else has done that with you so that you're not sure who else to share that with. That's why I still stay in relationship with other people who I've done pilgrimage with is so that we all share that knowledge of what we did together. Pilgrimage is a privileged time, privileged 
moment in which I realize not everyone is able to do a pilgrimage for whatever reason:

physical, spiritual, emotional, time-wise, work-wise. Sweet in which you are able to go home and be with people who love you, able to incorporate some the practices in pilgrimage that you were on in order to, in a more healthy way, navigate or negotiate your daily life in the here and now of your daily existence. So I'm better at doing that when I've just gotten off pilgrimage than when I'm far away from it."

For Avila, "It was bittersweet I think because I really enjoyed my time there, but I really didn't want to leave yet. So I felt like... I felt like I'd gotten a lot of benefit, but I just wasn't ready to leave so it was a bittersweet moment." For Bull, the return home gave him the opportunity to share with his children and grandchildren about his military experience as well as to reflect on his life. He stated, "Well, I think that anybody ought to be able to reflect on their life. I've thought a lot more the last ten years about my early life than I did during my early life, you know, because... we got out of the service, we went to work and nobody that I worked with out there, nobody that I...none of my friends knew that I was on the U.S.S. Enterprise."

\section{Is There Anything Else About Your Pilgrimage Experience That You Would Like To Share With Me?}

For Said, this question invoked a sense of justice for all pilgrims participating in the Hajj. He stated, "I went with a group from the U.S. and I feel that it - I mean, when you get five million people in the same place it's difficult to imagine different languages, different customs, different cultures, but I feel there are certain things that could be organized better, you know? It's easy to say, but I have to admit like when I see people piled on top on buses 
and things like that... I don't think that's a safe environment. And I really don't think God wants us to. It's a hardship, but I don't think God wants us to go to this extent where we put our life in danger. I mean, like I see a bus full of people and on the top of the bus you have another like forty or fifty people sitting on the top of the bus."

For Seth, this question prompted a hope that others may go on a pilgrimage. He stated, "I guess the, the main thing is that I would encourage people to take that kind of a journey; to connect with a place that your family, or a community of Jews, had lived."

Wild Bill noted, "I think, you know, the... I have this real deep, deep issue with the idea that America continues to send its citizens to fight and die for causes that the people that are sending them are not dedicated to, they're ambivalent about. They, you know... when someone dies in your arms that you care about there's nothing ambivalent about that... I don't think a ride to the Wall is going to resolve that for me. I don't think anything is going to resolve that for me."

\section{Construction of the Grounded Theory}

All transcripts were analyzed as a single unit for construction of the grounded theory. The steps of the coding analysis were the establishment of: (a) initial codes; (b) focused codes; (c) axial codes; and (d) theoretical codes. The coding process is outlined below and shown in Table 1.

\section{Initial Codes}

These codes were words or phrases that stuck close to the data and are action oriented (Charmaz, 2006). Initial codes included the following: 
Making meaning. All of the participants had some type of meaning making in their pilgrimage journeys. Ashanti talked about "grief of my mother, trying to find my new path...without her being there." Seth stated, "So, my feelings towards the Czech people were going to be, to some degree, shaped by these experiences."

Avila talked about her post-partum depression and the prayers that she encountered on her pilgrimage. She asserted, “Okay, I'm going to make this prayer the focus instead of my self-pity. I'm going to move towards being an instrument of God's peace."

Mike also remarked, "I would say that my pilgrimages have been the one thing that have helped me make the most sense out of my beliefs and my belief system." Christine found meaning in finding the source of many dimensions of her personality. She said, "There were these traits that I knew that I had that I didn't understand where they came from. This connection to always wanting to be a really good hostess. I really try to be, like, really on top of it when guests come, make sure everything's perfect, like, kind of like not really Martha Stewart, but just really wanting people to be comfortable and happy in my home. And I didn't really get that because my parents didn't have a lot of visitors in our house and aren't really super anal about stuff like that, but I had this really strong sense in needing to be hospitable and as welcoming and you know you're part of the family if you come to our house feeling. And even just, you know, I sang a lot as a kid and as a teenager and in college - I don't really sing much now - but where did that come from? No one in my family sings here. Just my, like, love of talking to people and getting to know people and these are all traits that I have in my family in Ireland.” 
Making a decision. The pilgrimage journey seemed to be a culminating event for participants and an endeavor that was thought about, often for years, prior to occurring. Ashanti stated, "With everything I had going on at the time, I felt it was a great opportunity to go."

Christine, stated, "I had thought about for three, four, five, six years and had never done anything and said, 'No this is not continuing anymore. I'm going. I'm done.'” Said remarked, "I always wanted to go. I, you know, when I talked to several of my friends who have gone before me they really encouraged me to go. I always kind of felt I wasn't ready to go because the way we were raised in Egypt is like this is almost like the last thing, you know, you perform in terms of religious duties. And, I always had this feeling that I wasn't, you know, I did not fulfill all other religious duties so this would be the last one, but they kind of encouraged me to go and said, "You know, if you wait until you're too old it's very demanding."

Walking. Many of the participants went on journeys in which walking was a component. Alcuin stated, "For three days in a row we were hitting twenty/twenty-five miles." Avila described, "They have, on their walking trails they have little decorative, like, little works of art that have little sayings and bible verses on them and then - I can't remember if it was on the walking trail or on the prayer labyrinth they have the prayer of St. Francis, you know, and it's to the effect of, 'Lord, let me be an instrument of thy peace, where darkness let me sow light' and a bunch of opposite pairs and I read that and it just resonated with me. And so I spent the whole rest of my time meditating on that prayer."' 
Feeling welcomed. Alcuin stated, "There would be a group from the church that would come out with its flag or its banner representing the church, as well as an icon as well as maybe their, maybe, tapestry of Our Lady of Guadalupe." Christine recounted, "The whole time we were there, they did not let us rest. We were on the move, someone was coming by, picking us up, taking us somewhere. So the first night was this giant dinner where they had over thirty relatives from all over Ireland came just to see us. It was ridiculous. People just came out of the woodwork..."

Ashanti stated, "I stepped off the plane, and these people don't even know what I've been through, like, help me understand. But you know why, that's because they love. The humanity of your brother and caring about your brother was there." Seth recalled, "The Czech people of the town were, once again, extraordinarily generous to us, and we were told later that their behavior was different than what we might have encountered elsewhere, uncharacteristically welcoming."

Connecting. The pilgrimage experiences as described by the participants were full of implicit or overt references to connection. Frida stated about one of the synagogues in the Czech Republic, "So I walk in there and I feel like I'm home in some way, and yet I, other than knowing that there are some Czech people who have the same last name as my father's family, I don't really believe that there's a direct connection, but there's some kind of a soul connection to this place that I can't imagine letting go of." About the land in Ireland, Christine disclosed, “And like I said, I'm not a farm girl, but I felt so connected there.” About his motorcycle pilgrimage to the Vietnam Wall, Wild Bill stated, "Oh, yeah. It is. It is a very, very bonding experience." 
Bringing home a momento. Bringing an artifact home is a meaningful way to remain connected with the pilgrimage. Alcuin stated, "And people have asked me when I've, when they know that I'm going to Chimayo, would I bring soil back for them."

Seth commented, "I also brought home a yarmulke that I bought in a synagogue in the Jewish quarter in Prague... It was meaningful to bring that back and have it."

Observing others. Said stated about the therapeutic value of his pilgrimage, "It's just the, the observation of what other people went through." Alcuin stated, "Charlie, he was in tears the whole time. I mean, this was so monumental because his family has gone through so much in life and so to share this time for him with his son-in-laws, with his grandchildren who were spry, who looked at him with such grandfatherly affection and grandchild passion, it was significant."

During Mike's pilgrimage, he encountered several men who were contemplating entering a monastery. Mike stated, "And so they were also sitting in the speaking dining room so we kind of got to talking to them. It was interesting to me, it's not - I mean, obviously it's - I mean, being a monk is not something that's in the cards for me or ever was in the cards or anything I ever thought about, but it's interesting for me to talk about it and talking to them about it, about how much of a different life it really is."

Praying. Said stated, "And of course the Day of Arafat where everybody is really, praying all day long." Alcuin remembered, "And then we spent the night in evening prayer. We spent the night, in fact, being prostrate before the cross that we will carry for the next few days, asking God to answer our prayers throughout the week." Frida recalled, "So while this 
group was praying in there, two strangers came in - very tall, both very handsome people, young - and they joined in; they looked in at the prayer service."

Contrasting. Many of the participants spoke about their experiences in terms of contrasts. Avila stated, "It was a good focus for me to play with the opposites... I was thinking, 'Where there's injury let me sow pardon,' I think that's one of pairs. And so I was thinking, 'What kind of injuries are there and how do you heal an injury?' And, you know, 'Where there's darkness let there be light."'

Ashanti talked about good versus evil: "My grandmother, my good grandmother - it's kind of like the good and evil grandmother which I can't say my evil grandmother was evil. She wasn't evil to us because she left us an inheritance, but she believed in evil things, you know?"

Mike stated, "So for instance, like at a Protestant church you may have no problem with making fun of Catholics, right? But when you go to a Catholic monastery and most of the people who are there are Catholic, you know, especially the pilgrims, then you tend to be more open to what, you know, to talking to them about things or to their belief system because you're really kind of playing on their turf at that point."

Marking time. For the participants in this study, the pilgrimage was a special point in time that separated that which came before from that which came after the journey. Frida stated, "It was a very important, it became an important touch stone for all of us, that each time we go, something shifts." Alcuin noted, "It's almost - it's a touchstone so I remember exactly where I am, who I am, what I do... so that's the importance of it for me.” 
Becoming aware. There were points during the pilgrimage in which the participants had an awakening. Mike stated, "So, you know, it makes me stop and go, 'Wait. When am I worrying about me? When am I worrying about what's going on, you know, with me? Not physically or anything like that, you know, because I can feel pain, right, but, like spiritually or emotionally it's like, am I really happy at work? Have I thought about if I'm even happy at work? When was the last time I even stopped and went, 'Am I growing spiritually? Am I really on my journey, you know, with God? Am I taking steps forward on that path?"’ Wild Bill recalled, "I realized that I needed to resolve some of those conflicts." Christine asserted, "I realized that I've always identified as Irish and always felt very akin to that, but I had never actually gone and experienced that."

Reflecting. Reflection seems to be a significant part of the pilgrimage process. When asked about this, Bull stated, "I think that anybody ought to be able to reflect on their life." Mike encountered others that differed in their faith from him and remarked, "It was good for me to kind of get an idea of where other people that I interact with a lot, you know, day to day, kind of where they're coming from and kind of what their perspective is on certain things. And so it kind of makes me wonder, like, what... like, it kind of makes me think about the things that don't make sense to me or that kind of freak me out or that I have strong reactions to that other people don't. And so like, why am I uncomfortable with certain things that other people are comfortable with?"

Forming a group identity. Alcuin stated, "We have all received, there's always a shirt that's designed for the pilgrimage. Each year's pilgrimage shirt is different, t-shirt is different; this year they didn't do that. We were given all crosses - no, we were all given 
scallop shells from Santiago de Compostela." Wild Bill talked about the importance of symbolism in his group, "And if you know how to read the imagery, you know, you would know who you were around very quickly, you know? The necklace that I wear is... it's the colors of the ribbon that you wear on your uniform from people that have served in Vietnam, you know? So anybody who has that ribbon, you know, would understand what that means. So the imagery, you know, like she says the tattoos, the symbols that you wear probably speak for you."

Said commented about himself and others, "They all wore the same type of clothes; they all were praying to God. They are all equal so that was very moving to me."

Participating in ritual. Ritual is one of the primary elements about pilgrimage that has been observed. Participants in the current study engaged in various types of rituals. Said stated, "Before you leave to go back to your country, you do Tawaf dua which is the farewell."

Will Bill stated, “There's kind of a ritual, you know, you ride all day, get to a motel, everyone gets cleaned up, you eat a meal and then you meet somewhere... you know, a parking lot would be our common scenario, everyone drags a chair out of a room, sits in a circle, and then you drink and talk and talk about everything, but you talked about the war."

Being comforted. Finding comfort in the pilgrimage journey was an interesting finding. Said explained about pilgrimage, "It is like when was a boy in Egypt and I would have a fight with my parents. I would run to my grandmother's house and she would comfort me. That is what pilgrimage is; when there is stress in the world, you can run to the House of 
God [Ka'aba] and you will be comforted." Ashanti stated, "I knew God could be a comforter, but I really, really didn't know that He could until I took this pilgrimage to Africa."

Going home. Most of the participants in this study spoke in terms of the home motif. Christine stated about her pilgrimage, "Everyone kept hugging me and coming up to be and saying, 'Welcome home' and that was a really powerful experience to feel like they were taking me home. And I felt very at home, I mean, this is out in the middle of the back woods of Ireland - out in the back woods of Ireland, like there was nothing there. I am not the kind of person that likes farms or anything like that, but that's where my family's from and I felt such a strong sense of connection to the place and to people in a very short period of time."

As Alcuin approached the Chimayo chapel he recalled, "You could hear this [singing and a mariachi band playing] as you were approaching and then when you're entering in, it just consumes. And now having done this now over a span of thirteen years, I now know enough people so that you recognize people that you've done pilgrimage with - my first time, the second time I've done it, now this might be my third so that there's a real sense even though, you know, even though I - there are, there are those who've done it more than I - I knew enough people this time that it was so good to see their faces because we had already shared that moment with us."

Gaining knowledge. One component of pilgrimages is gaining knowledge about a particular place or people. Ashanti stated, "The purpose was to learn about the history of Africa - the Trans-Atlantic slave movement." Alcuin stated that along his pilgrimage journey, "We would learn the history of their church or their chapel. Then we would always have food and there was always involved with the food, there was always prayer before the 
food was eaten; there was always a prayer after the food was eaten. So between the prayers, the kissing, the genuflecting, the history lesson as well as time of resting there was always moments in which our feet would have to be bandaged up or lancing blisters."

Eating. Sharing a meal with others played a role in every participant's experience. Ashanti stated, "They made breakfast for us, we had lunch and dinner so they make sure we had three meals. And that was really important because I'm not accustomed to that in America. Like, making sure that I sit at the dinner table and eat three meals a day and someone was concerned, 'Well, did that taste good to you?' Like, they were really concerned about the food and if it was good and if you had enough so that was neat to see the care as I was talking about the love and the concern."

Frida noted a community banquet during the pilgrimage to the Czech Republic. She stated, "There was a reception, and this time the town itself insisted on hosting the reception, and they wouldn't let us pay for it, and the vice-mayor was baking. I mean all of these townspeople, actually it's mostly the women and they kind of corral their husbands in to help out, put out this really quite lavish reception for us."

Alcuin stated, "I think that the meals are highly important because they're a sign of true hospitality. And I'm always amazed at and aware of that in a meal, differences are glossed over and we find common ground in simply asking for bread or for sugar or for salt or for pepper; that conversations with strangers ensues and strangers soon become friends. And so even with the people that we had not known at these various places, we're suddenly becoming friends with them and I like that." 
Recognizing generational legacy. Participants seemed to find meaning in connecting with those younger and older than them as well as with those who have died. Christine stated, "I was kind of overwhelmed honestly throughout the whole time I was in Leitrim and in Drumshambo and I had told everyone that I needed to take a nap and they were like, 'Oh, well we wanted to swing you by the graveyard. It's really, you know, it's the anniversary of our dad's death, we thought... is that okay with you?' And I said, 'Yes, that's okay. It's family and it's important and we're definitely going there.' And he kind of turned around and he looked and me and he was like, 'That is exactly what your grandfather would've said.' And that was a really powerful moment because I never really knew my grandfather; he passed when I was two. So to know that there's some sort of a connection and a value system that's being passed down and it connects beyond you and it's something that is very old, that made me feel spiritual."

About his Islamic pilgrimage, Said remarked, "You see somebody who is, very old and he had, like, was carrying his child and apparently his child was, had some physical disability or something. And you can tell this, this father was, you know, he came with his son and basically he was standing there and just praying for God and asking God, telling Him, 'God, you told us you pray for me. I will respond to you.' And it just... something like that really moved me."

When Bull went to the airport to depart on his flight to Washington D.C., there were several military groups in uniform at the airport. About this Bull stated, "Well, it means a lot and it means a lot to me to see these young fellows or young people now in their uniform. And I, as much as I can, will thank them for their service and I've had hundreds of people - 
since I wear my U.S.S. Enterprise hat - stop me and thank me for my service; old and young and in between."

During Alcuin's pilgrimage journey to Chimayo, he was in a group with a grandfather, a son, and a grandson. He remarked, "This was three generations of pilgrims before us. Now Charlie, the grandfather, is also a penitentes. The penitentes are a group of lay people, lay men, not lay women, but laymen who, they understand their heritage comes from Spain in which the penitentes always maintain the church and the Catholic faith, even when the priest may not be around, the brotherhood has always been there. And Charlie is a penitentes and they own houses next to churches called moradas and Charlie speaks Spanish (Charlie is Spanish-Catholic) but what was interesting was there's no evangelism. You have to ask to become a penitentes, none of the sons-in-law nor the grandchildren have asked to become a penitentes, but they did go on pilgrimage with him and I think that was, in Charlie's estimation, that was as good as it was going to get. So that's why it was so moving for him to have this and to know that this was his last. His body, to be honest, he moved faster than I did, I don't know why he said it was his last, but just watching his love throughout the week was itself moving for me."

Giving back to others at the pilgrimage site. Frida stated, "For those that are drawn to worship when we're there, we have created a prayer book (in Czech, English and Hebrew) that we've left there so that, somebody else can lead a Saturday service, Saturday morning service, a Torah service if they wanted to."

Christine described her contribution: "I guess the one thing I did - I went out to Southern Season and spent like five hundred dollars on gifts and things for the people there 
because I wanted to - I didn't want to just go and be like, 'Hey, I'm showing up and I'm taking all your stuff and, you know, you're going to drive me around town and then we're going to leave and you're never going to see me again.' I wanted to kind of form that relationship so I bought all sorts of things that were from North Carolina because I thought that would be a nice way to bring my world to theirs. We made a photo album of everyone here to take there so we could, again, form that bridge."

Ashanti recalled, "When I went on the pilgrimage I carried a suitcase full - and this is how God works because last year, school time, Staples had a sale and so I was buying for the kids at school pencils, notebooks, erasers, everything. And so I kept it in my office for a whole year and, you know, I would give it to the kids, but nobody really, you know... so I'm like, 'Okay I'm going to Africa, we're going to do a service learning project at the school.' So everything I had bought out of my money, that filled the suitcase to give to the kids at the village and every kid got a pencil, every kid got a pen, every kid got an eraser.”

Being an ambassador. Christine stated, "I felt like I was the ambassador for our family so there was a lot of nerves there and I was surprised because I'm not usually an anxious traveler." Alcuin explained, "So people write, we actually have people, we have a preset form that people can fill in or else people along the way will give us. People will put it in our hands, prayers, or put it in our pockets. I've had people come up without my knowledge that they were going to do it, throwing prayers into my pockets. I've had people simply say, not knowing that I was a Presbyterian minister, but knowing that I was a pilgrim to Chimayo, they said, 'Would you bless me' and will take off their hat or their glasses and 
expect to be blessed by me because the understanding is that the pilgrim is one who is giving a sacrifice of time, energy - time and energy to do this. We are holy messengers."

Gaining perspective. Mike suggested the pilgrimage was "therapeutic in the way that it kind of helped me see different ways to deal with my own stress or help me to figure out what my priorities are and what the distractions are, I guess, in life." Avila stated, "Well, I definitely think I had a new perspective on life, on the depression that I was struggling with. In that I was able to... I was able to see where I was being self-pitying and kind of shake myself out of it and I was also able to see that I would get better. I mean, it was like I was like, 'Okay, I'm still depressed.' I mean, at the time I was still depressed, but I was like... it's going to get better. It was almost like I was down at the bottom and I was climbing back up."

Alcuin affirmed, "Well that's what pilgrimage is. I'm amazed at what I've gone through that I didn't know I would go through or had only a kind of sense about that I would go through a week earlier. And so the pilgrimage, the journey itself becomes so monumental, but the destination gives me a chance to sit back then, put my feet up, if you will, or assume a yoga pose of criss-crossing my legs and just going, just reflecting, just pondering what all has gone on within a week's time that I may not have been able to be aware of at the moment, but given that moment of reflection at the destination point gives me a moment to celebrate, to look at the "Aha' moments with new eyes and a new heart."

Witnessing serendipitous events. Many participants believed they were part of serendipitous events during their pilgrimage journeys. Bull stated, "So as we left the main gate [at Arlington Cemetery], it was probably about half a mile in to where the tomb of the unknown soldier is, on the way in there he told me that I was going to be one of them that get 
- nobody knew that we were going to lay a wreath on there except our guide until we were actually on the grounds." Christine described, "I actually sat next to a priest on the plane like, it was just weird stuff kept happening that kept making me feel drawn into kind of a greater sense of being and a greater sense of purpose. And I feel more spiritually awake than I have in the past."

Seth recalled, "There was an elderly woman who came on the bus and slowly started talking about her experiences during the war [World War II]. During her narrative, she mentioned that she had been in Theresienstadt and that she was on the last train from BergenBelsen to Theresienstadt. And that was the same train that Moses' mother had been on. So this woman, who joined our group accidentally, was on the same train as Moses' mother. This coincidence, or not a coincidence, gave all of us a shock. Moses was of course very moved by finding a person who shared this harrowing experience with his late mother. Moses spoke to her further, both on the bus and later in Heřmanův Městec. But the powerful element was that Moses, and our group, were joined by someone who had this 60 -year-old connection of a train trip and imprisonment in Theresienstadt that his mother experienced. That was also really an extraordinary moment."

\section{Focused Codes}

Focused codes are created to begin to synthesize the data from the initial codes (Charmaz, 2006). Based on the above initial codes, focused codes were identified and are explained below.

Using the body to engage in pilgrimage experience. This code synthesized the initial codes of eating, praying, walking, and bringing home a momento. In all of these initial 
codes, the participant is using the body in a component of the pilgrimage experience. For example, Alcuin stated, "I think what's beautiful is there really is a possibility of integrating mind, body and spirit in which you understand the power of the body to do things when the mind says you will do it. Even though the body is saying 'I'm hurting, I'm hurting, I'm hurting' that you are able to push yourself farther than you thought you were able to do. I think there's also - the folk philosopher and farmer Wendell Berry makes it clear we think, as our thinking process is about the same rate by which we walk which only makes sense that the heart beats at a certain rate."

Connecting with self. This code captures participants' experience of becoming aware of an authentic feeling or thought. In addition, the code subsumes the decision-making process engaged in by the participant and recognizing generational legacy. An example of this process of connecting with self occurred for Christine while she was in Ireland. She stated, "I was kind of overwhelmed honestly throughout the whole time I was in Leitrim and in Drumshambo and I had told everyone that I needed to take a nap and they were like, 'Oh, well we wanted to swing you by the graveyard. It's really, you know, it's the anniversary of our dad's death, we thought... is that okay with you' and I said, 'Yes, that's okay. It's family and it's important and we're definitely going there.' And he kind of turned around and he looked and me and he was like, 'That is exactly what your grandfather would've said.' And that was a really powerful moment because I never really knew my grandfather; he passed when I was two. So to know that there's some sort of a connection and a value system that's being passed down and it connects beyond you and it's something that is very old, that made me feel spiritual." 
Connecting with others. This code subsumes the experience of the participants in which they felt welcomed and witnessed serendipitous events. In addition, the code captures the experience of participating in ritual, forming group identity, giving back to others at the pilgrimage site, going home, and recognizing generational legacy. During Frida's pilgrimage to the Czech Republic, she was with a group that visited the St. Vitus Cathedral in Prague. While in the cathedral, two of the pilgrimage leaders observed a place that appeared to be the navel of the cathedral. Frida recalled, "And so we gathered all of the folks who were scattered around looking at the cathedral and we stood there for a while in silence and felt whatever it was everybody was feeling, we did a little bit of chanting - there's a verse from Genesis, when Jacob wakes from his dream and says, 'How awesome is this place?' Everybody took a turn standing in the center of the group and feeling whatever they felt, and it was pretty striking. It felt like we were standing in a place where there was a tremendous amount of spiritual liveliness, and we were drawn together as a community because we were standing pretty close together like this ... and there was this energetic circle ... and giving everybody a chance to get a feel for whatever was going on for them."

Connecting with history. This code synthesizes the participants' experiences with recognizing generational legacy and the process of gaining knowledge. Ashanti learned about the history and culture in West Ghana as well as connected with the granddaughter of the family with whom she stayed while she was there. She stated, "So anyway, we stayed with them and it was really interesting to see, you know, the culture there of how - in America, we work for other people whereas in Africa, they're entrepreneurs. You know, to see how they wake up 4:00 in the morning to make it to the city of Acrai [?] so that they can sell items 
such as necklace, jewelry, whatever it is, water, candy... and to walk up and down the highway, day and night, sweating in hot sun just for fifty cents. I'm just like, I was just bewildered like, 'Oh my gosh.' And so that gave me a better appreciation of the hard work that I have done and how to really take the time to enjoy life. And so we stayed with the host family, they had a little - their granddaughter, Macoffee [?], she was really connected with me and so every day after school, you know, I spent time with her playing tea and things like that."

Figuring out priorities. This code emerged from gaining perspective and making meaning. Christine realized during her pilgrimage to Ireland that the connection she found with her family was so significant that she desired to continue to the legacy. She stated, "I mean, coming home - and like I said I came home on Friday and we had this talk, the most definite talk we have ever had about having children that Sunday."

Recharging batteries. The privileged time of a pilgrimage led to recharging batteries. This code is an in vivo code, which is a specialized term used by participants that has special meaning (Charmaz, 2006). Said recalled about his experience on the Hajj, "It, it's, like we're all busy with our daily lives and we're running, we're in a race, too much stress, too much worries, and it's almost like you go over there; you completely disconnect from the rest of the world. It is between you and God. You basically feel it's almost like recharging your batteries if you will."

Contrasting. This code subsumes the initial code of contrasting and emerged as its own focused code. Every participant spoke about how pilgrimage was a different experience than the routine elements of life. Three of the participants spoke about the pilgrimage as 
having overt or covert Catholic overtones and they are not Catholic. Mike stated, "And so I, you know, it's... you know, talking to these other folks, like, you know, in these, you know, on these pilgrimages where I would not - these are people I would never have encountered. I'm not a Catholic. I've never even thought about being a monk. I've never thought about being clergy. I've never thought about any of that, you know?"

Observing others. This code is also an important code in the data synthesis and emerged from the initial code of observing others. When Wild Bill arrived in Washington DC on his motorcycle pilgrimage, there were masses of people lining the streets. He stated about many of those in the crowd, "Yeah, and an amazing number of wounded and disabled, you know, guys that couldn't ride were there on the boulevard...guys without an arm, a leg or..."

\section{Axial Codes}

Axial codes relate "categories to subcategories" and "specify the properties and dimensions of a category" (Charmaz, 2006, p. 60). The axial codes that emerged from the focused codes are defined below.

Physical or biological connection. Participants connected in a physical or biological way during the pilgrimage journey. Alcuin described the process of gathering soil on the route to Chimayo: "In fact, when you're making the pilgrimage to Chimayo, at each place that we have a meal, at each place that we have a prayer, at each place that we have an encuentros, we take a - we ask for the soil from the various places and then at the great gathering at the destination point on that morning, we - all the pilgrimage sites because there are pilgrimage groups, there are five pilgrimage groups. One group leaves from Costilla, 
another group from Chama, another group of Albuquerque, Bernal and Estancia and everyone takes their satchels of holy earth and pour it on a common place so that it is seen as soil that is blessed."

Psychological connection. The participants connected with themselves, with others, and with the land. Mike stated about his pilgrimage, "It's something that is now part of my life. I don't go every year, but I know that it's something that I will always do. Doing it the first time was difficult because, of course, you know, it's different. It's just not something that seems like a whole lot of people do or if they do it they don't call it pilgrimage. And so it's, you know, it's one of those things, it can be very scary to think about spending time with, you know, like I say, others or by yourself or whatever, you know, just out of your normal, everyday element. But it's something that I need to be able to appreciate or make sense out of my normal, everyday element."

Recalibrate. This was also an in vivo code. Participants spoke of their experiences in a manner in which they were able to gain perspective and set priorities during their pilgrimage journeys. Additionally, the pilgrimage was a specific point in time in which the participants noted as time for themselves.

Alcuin stated, "I think the actual intentional pilgrimage provides a time of recalibration so that I'm actually, my body is actually reminded and tweaked to and given the experience of a journey so that I know that I am, in life, metaphorically and figuratively and literally on an ongoing process of journeying. So how do I greet whatever comes along in my life now more as a pilgrim rather than not as a pilgrim? And that's why it helps is just I need 
to be reminded, I need to recalibrate, I need to touch that moment again just to be sure, 'Oh yeah, that's right. I'm on a journey, I'm on a journey."”

Contrast. The pilgrimage journey was a noted departure from the participants' routine and schedule of life. Further, the participants categorized particular events and people in a dichotomous nature. For example, when asked if the pilgrimage was getting away from the routine, Mike stated, "Right, absolutely. Sure."

Social connection. The pilgrimage journeys led to connection with others through conversations, learning about others, and through rituals. Seth recalled his pilgrimage experience in the Czech Republic, "I think about the people we met, what their lives are like, how gracious they were to us. And I think about a healing service that we held that clearly was powerful and meaningful for the townspeople. During the service, each person took the opportunity to hold the Torah as long as they wished. We invited them to communicate with it, to ask for whatever they wanted, to communicate as they wanted to. This seemed to have a profound effect on many of them."

Legacy. This axial code subsumes the connecting with others, connecting with history, and gaining perspective. Ashanti stated, "So I'm definitely changed, like, I have a greater appreciation, you know, of family and carrying out the legacy and I want to be able to continue that legacy that my mother left and those values because my mother was a sweet person, you know, she just didn't know how to cope with the issues and challenges that were presented for her."

Homecoming. Participants reported a sense of homecoming. Christine stated, "I think it made me more comfortable with what I already am and allowed me to want to be that 
person. Like I said, I just have this stronger sense of rooting than I've ever had before. There's just, like, I'm there, I'm with them. I am, you know, I think about them just, like, throughout the day and I feel a really strong sense of connection to my family here and my family there."

Spiritual connection. This code subsumes connecting with God and connecting with self. Said spoke about this: "And just, you know, call to prayer, all of a sudden everybody is standing up, all the lines are straight - well, in this case, I guess, around the Ka'aba. Uh, it's really amazing. It's just like you, you're living there, you know, like, your day and night is you're worshiping God. That's the only thing you're thinking about. There's nothing else in your mind, completely outside, you know? I mean, whatever happened, the rest of the world is none of your business."

\section{Theoretical codes}

Theoretical codes "specify possible relationships between categories you have developed in your focused coding" (Charmaz, 2006, p. 63). Further, they "weave the fractured story back together" (Glaser, 1978, p. 72). The theoretical codes that emerged from the data are: (a) biological therapeutic value; (b) psychological therapeutic value; (c) social therapeutic value; and (d) spiritual therapeutic value. These codes are conceptually interrelated as each code is linked to a dimension of the human experience and the linkage of the terms is congruent with an emerging construct in the helping professions. The terminology of the bio-psycho-social-spiritual model has its origins in the domain of addictions treatment. In recent years, there has been an increased interest in empirical inquiry using the biopsychosocial model. Topics under review include pregnancy and stress (Dunkel- 
Schetter, 2011), aging (Inui, 2003), infertility (Gerrity, 2001), cancer treatment (Sulmasy, 2002), and therapy (Duba, 2005). The addition of the spiritual component was subsumed under the social component of the model, but has emerged as its own domain after scholars concluded that religion and spirituality warrant a specific focus. 


\section{CHAPTER FIVE: DISCUSSION}

In this chapter, the results of the study are explored and connected with prior research and pilgrimage accounts. Further, the limitations of the study are discussed and the implications for research and practice are provided. The purpose of the study was to utilize a constructivist grounded theory design to answer the following questions: (a) How is a pilgrimage journey therapeutic? (b) What meaning is assigned to various points in the pilgrimage process? and (c) How are religious and nonreligious pilgrimage experiences similar or different?

\section{Integration of Study Results with Theoretical Underpinnings and Prior Research}

The theoretical paradigm for the current study was positioned in the synthesis of traditional and contemporary pilgrimage theory, personal construct theory, and multicultural counseling theory. In the following discussion, the results of the study are explored within these theoretical frameworks.

\section{Pilgrimage Theory}

All of the participants in this study chose their respective pilgrimage journeys because of the significance of a particular site or sites. Consistent with the conclusion by Spencer and Spencer, participants chose a specific site because it was: (a) inherently spiritual; (b) the site seemed chosen by a divine power; or (c) the site was a place in which people invested their belief or emotion (2002).

Participants also demonstrated evidence that their pilgrimage journeys were a social phenomenon. A sense of liminality was described by the participants during which the participants' daily routine was suspended and they were in a place of "neither here nor there" 
(Turner, 1969, p. 95). For example, Said's account of his Hajj experience supported the notion that his religious position changed between the start of his pilgrimage and the end of his pilgrimage at which time he had fulfilled a core tenet of Islam.

Further, the experience of the participants is congruent with Turner's descriptions of communitas. In specific, Ashanti, Said, and Mike disclosed that they felt close to humanity and saw a glimpse into "mankind as a homogenous, unstructured and free community," a phenomenon Victor Turner labeled existential communitas. (1974, p. 169). The second type of communitas noted by Turner, ideological communitas, was not evident in the participants' experiences. Perhaps this type may be observed on prolonged pilgrimage journey as the basis is a mobilization of the group and an organization of resources. Ideological communitas, the third type identified by Turner (1974), applies to utopian models or blueprints of societies based on the pilgrimage experience. All of the participants remarked about feelings of love, comfort, or acceptance that they felt during the pilgrimage experience. As a result, they vowed to implement these characteristics, or search for new ways of expressing them, in their lives.

Turner and Turner (1978) outlined four types of pilgrimage: prototypical; archaic; medieval; and modern. Said's pilgrimage fell under the prototypical classification as the pilgrimage site was established as part of the historical religion, Islam. Alcuin's pilgrimage could be categorized as archaic because the Chimayo site was historically significant prior to the establishment of a chapel on the land. In this study, there was an absence of medieval pilgrimages and the remaining eight pilgrimage journeys can be classified as modern. A modern pilgrimage is characterized by the personal characteristics and experiences of the 
pilgrim, yet still has a religious focus as described by V. and E. Turner. However, scholars of contemporary pilgrimage expanded the definition of pilgrimage beyond a religious context and have concluded that pilgrimage does not necessarily have to be religious in order to be classified as a sacred journey (Courtney, 2013; Smith \& Puczkó; Winkleman \& Dubisch, 2005). Because of the significant meaning derived from the pilgrimage experiences, all of the journeys in the current study can be considered sacred.

With regards to steps in a pilgrimage process, the majority of these steps, as described by Davidson and Gitlitz (2002), were confirmed by the study participants. All of the participants recalled a specific time when they made a decision to embark on a pilgrimage journey. Additionally, they described specific preparations undertaken for the journey and discussed the pilgrimage in comprehensive terms. Finally, all of the participants recalled their return home after the pilgrimage. While useful in the interview protocol for prompting participants to recall specific time points in the pilgrimage journey, the focus on these time points during the interview seemed to detract from the participant's narrative. It seemed that the pilgrimage steps may be best utilized in the observation process rather than as a framework for a semi-structured interview template. It was evident that the participants found meaning in a contextual description of the pilgrimage journey. These contextual factors included details about people, the natural setting, and feelings that were experienced during the journey. These rich descriptions of journey in its entirety confirm that pilgrimage is more than the sum of any one part (Winkleman \& Dubisch, 2005).

\section{Personal Construct Theory}


The notion of religious versus nonreligious pilgrimage was the focus of the research question "How are religious and nonreligious pilgrimages similar or different?" The basis of the answer to this question is steeped in the participants' personal constructs. Four participants in the study categorized their pilgrimage as religious, two participants categorized the pilgrimage as secular, and four participants categorized the pilgrimage as both religious and secular. The religious or secular constructs were present for all participants prior to the pilgrimage journey. For example, Said participated in the Hajj because it was a component of his Islamic faith. The pilgrimage was a step in a greater journey of personal and communal religious practice. Frida and Seth had a personal connection with religiously significant sites in the Czech Republic and chose this particular country because of its religious dimensions. These experiences of the participants are congruent with Kelly's personal construct theory because the participants retained the constructs that had predictive value (Kelly, 1955). In these scenarios, the participants retained the religious construct that was present prior to the pilgrimage. Said was a Muslim before the journey; his intention for making the journey was religious in nature; and the journey affirmed his Muslim identity and practice. A similar pattern existed for Frida and Seth. They both practice Judaism, yet are committed to interfaith dialogue. The pilgrimage group was comprised of Jews and Christians who had shared a year together in deep, interfaith dialogue. One of the purposes of the pilgrimage was to foster visceral experiences (related to Holocaust sites) for the group. The interfaith dialogue continued on the pilgrimage, and was retained both during and after the journey. 
The above are examples of religious constructs. However, secular constructs were also exhibited in the study. Bull was on the USS Enterprise during World War II and carried the memories of experiences on the ship. In addition, he was part of a community of veterans who served on the same vessel throughout modern history. Consequently, his pilgrimage was based on his military constructs. These military constructs were retained and strengthened as a result of his journey.

Further, Christine both retained her secular construct related to her Ireland pilgrimage and gained a religious construct as a result of the journey. At the onset of the journey, she did not plan to have a religious pilgrimage, but certain events occurred and altered her personal construct of the experience. This led her to categorize her experience as both religious and secular.

The results of this study indicate that both religious and nonreligious pilgrimages share characteristics. These include: a connection with self and others; a focused time to reflect, prioritize, and recharge; and finding one's place in time (i.e., recognizing that there is a direct line of humanity before and after one's existence). There was only one notable difference between the religious and secular pilgrimages and that was the theme of prayer. The participants who categorized their pilgrimages as either religious or both religious and secular spoke about praying as part of the pilgrimage experience. The prayers or act of praying seemed to be focused on an outward type of prayer, rather than on an inward meditative type of prayer. It is possible that there are multiple types of prayer and these may have been present in the secular pilgrimages. As noted by Collins-Kreiner (2009, p. 443), 
"The poles of the pilgrimage-tourism axis are labeled sacred and secular respectively. Between the two exists an almost endless range of possible sacred-secular combinations."

Linear versus non-linear pilgrimage. The results of the current study confirm the above assertion that there is an endless range of sacred-secular pilgrimage combinations. For the current study participants, the religious versus secular categorization did not seem to be as binary as the interview template implied. Rather, the pilgrimages appear to be lightly differentiated by the dimension of linearity. For Said, Alcuin, Wild Bill, and Bull, the pilgrimage route and activities were established prior to the commencement of the journey. As such, there was a more definitive idea about the expectations of the outward aspects of the pilgrimage. For example, Said worked with a tour operator as is the custom for the Hajj pilgrimage. Alcuin walked a specified path to the Chimayo chapel. These pilgrimage journeys had an established final destination. This type of pilgrimage is consistent with assertions that pilgrimage is a site-specific phenomenon and that "pilgrimage is a journey undertaken by a person in quest if a place or a state that he or she believes to embody a valued ideal" (Morinis, 1992, p. 4).

Avila, Mike, Seth, Frida, Ashanti, and Christine went on pilgrimages that did not have pre-determined destination points and were open for an evolving itinerary. The general pilgrimage journey was established prior to departure, but the events during the pilgrimage were informed by multiple factors. The outwardly changing circumstances provided an opportunity for the integration of real-time reflection and pursuit of significant experiences and relationships that seemed to result in a robust pilgrimage journey. 
Regardless of the linear dimensions of the pilgrimage journeys described in the current study, all of the participants reported that their pilgrimages were a significant life experience. Collins-Kreiner (2009) recognized that contemporary pilgrimage exhibits postmodern characteristics and experiences and meaning are constructed and reconstructed. Thus, it is possible that the meaning in a linear journey may emerge after the pilgrimage is over while the meaning in a nonlinear journey may be constructed as the pilgrimage unfolds.

\section{Multicultural Counseling Theory}

The multicultural counseling notion that individuals construct their worlds through social processes (Sue et al., 1998) was evident in the current study. For this study, pilgrimage was the social process; however, previous social processes informed the pilgrimage before and after the pilgrimage, and social processes contributed to the meaning. As mentioned in the discussion above, the pilgrimage was not an isolated event for any of the study participants. The particular sites were chosen because of the their meaning. Christine chose Ireland because of her ancestral history; Said chose Mecca because of its religious significance; and Bull chose the World War II memorials because he was a combat veteran during the war. The actual pilgrimage provided a context for reflection, growth, and questioning and these processes occurred within the participants as well as between the participants and others in their spheres. After Christine's pilgrimage experience, she and her husband decided to have children; Ashanti decided her life was too busy and she needed to slow down; and Avila realized she could interact with her baby in a more healthy manner.

Another tenet of multicultural counseling theory is an emphasis on the role of spirituality in coping with identity issues, hopelessness, and feelings of powerlessness 
(Fukuyama \& Sevig, 1999). This spirituality does not necessarily relate to organized religion nor does it inherently imply a particular belief in a power greater than ourselves. The results of the current study indicate pilgrimage may be one way to address the role of spirituality for a multitude of religious adherents as well as for those who consider themselves non-religious. For example, Wild Bill reported that he did not affiliate with an organized religion, but found significance and meaning in his motorcycle pilgrimage to the Vietnam Wall. A similar report of meaning-making was documented in Said's Hajj pilgrimage.

\section{Pilgrimage's Therapeutic Value}

A primary objective of the current study was to answer the question "How is a pilgrimage therapeutic?" The results of this study are congruent with the assertion that the therapeutic value of pilgrimage can be categorized as "biopsychosocialspiritual" (Winkleman \& Dubisch, 2005, p. x). Participants identified therapeutic attributes in the biological, psychological, social, and spiritual domains. The codes, or themes, identified in chapter four indicate that pilgrimage is more than any one component and should be viewed as a comprehensive, or holistic, endeavor.

\section{Pilgrimage as Self-Care}

Because of its rich therapeutic value, pilgrimage seems to be the ultimate act of selfcare. The preparations for the journey as well as the actual pilgrimage are therapeutic. Participants in the current study reported that, once the decision was made to go on the pilgrimage, there was excitement that energized daily life. The journey also provided the context for examination of priorities, time away from responsibilities, and space to place life's experience into a framework of meaning. Five of the participants categorized their 
journeys as a pilgrimage prior to the beginning of the experience. The remaining five classified the journey as a pilgrimage only after learning about the meaning of the term pilgrimage. This illustrates the importance of the actual word and provides a construct for travel that has a special goal. Phil Cousineau stated about his journeys, "By naming my journey a pilgrimage, he [Ahmet, a young Egyptian friend] had conferred a kind of dignity on it that altered the way I travel ever since" (1998, p. xx). By utilizing the construct of pilgrimage, individuals can engage in a therapeutic process in which they may not otherwise engage.

For example, Mike commented, “And it's very interesting because our corporate culture is such that there's very few things that people will ever say, when they're off of work, that they're just completely unavailable. And so those things are either - those things are always interesting. They're either, you know, bad in that, you know, I've got some medical issue I've got to go deal with or they're good in that I'm going to be climbing Mt. Everest or whatever, you know? And so it's interesting, so whenever you say and you go out of your way to tell people, 'I am not going to be available this week,' then, you know, some folks will, they don't want to know if it's bad so they'll just ignore it, but a lot of people will actually ask. Like, 'You're not going to be available, where are you going to be that you won't be available?"”

\section{Pilgrimage as an Intervention}

There are many published personal accounts of pilgrimage. Examples of the themes of these autobiographical narratives include making a life transition (Bolen, 1994), building a foundation for interfaith respect (Feiler, 2002); and establishing a life practice of pilgrimage 
(Cousineau, 1998). While these accounts do not overtly address that pilgrimage could be a therapeutic intervention, they certainly provide the context for this idea. In the current study, Ashanti described the importance of pilgrimage in the life transition from having her mother as a close confidant to losing her to cancer. Christine discussed her need to connect with her Irish heritage for both personal and professional reasons and Alcuin indicated that he relies on his practice of pilgrimage for recharging his batteries and recalibrating his life. It is evident that a pilgrimage journey can be a self-contained intervention. Details of this assertion are provided in the following section.

\section{Study Implications}

The results of the current study support the notion that pilgrimage has both individual and societal implications. These implications are explored below through the lens of the counseling relationship as well as through the lens of the counselor training context.

\section{Individual Implications}

The study has a myriad of personal implications. The pilgrimage journeys described by the participants had a significant impact on their thoughts about life, their relationships, and their future plans. From a counseling perspective, it is crucial to be aware of past pilgrimages in a client's history. A simple question about a past pilgrimage could easily be added to an intake assessment and could provide voluminous data for the counselor at the beginning of the therapeutic relationship. Further, if the pilgrimage is part of a client's religious framework, the developmental context in which the pilgrimage occurred would also be of use to the counselor (i.e., Fowler, 1981). 
Moreover, a counselor could develop a niche specialization in working with religious pilgrims both in the preparation process as well as in the reintegration process. Part of this specialization would include training that addresses the common stages of the pilgrimage process as well as in religious development models with a particular focus on transitional points through which individuals move from one stage to another. A specifc consideration for counselors working with religious pilgrims was addressed in the study by Sandage, Jankowski, and Link (2010) in which the authors noted that individuals who reported a recent spiritual transformation also reported a higher level of anxiety than those who did not report a recent spiritual transformation. With regards to working with clients who are preparing for a pilgrimage, it is important that counselors address possible anxieties that may result from their experience. This may be further compounded when an individual is a member of a group going on a pilgrimage journey and may have a different experience from the other group members or may return with questions about the belief structure of the group or religious establishment that promoted the pilgrimage.

Another potential possibility for counselors is the publication of some type of handbook for pilgrims to use in preparation for and reintegration from a pilgrimage. This book could outline the research on the topic of pilgrimage through a contextual and historical framework. Additionally, the stages of a pilgrimage could be delineated as well as reflective exercises could be added that (a) assist in the preparation for the pilgrimage, (b) help pilgrims create meaning during the pilgrimage, and (c) assist them in integrating their pilgrimage experiences into larger religious/spiritual, psychosocial, and moral identity frameworks. 
From the perspective of counselor training, a personal pilgrimage could be an integral component of the educational experience. The experience would provide the opportunity for self-reflection and expansion of perspective. In terms of counselor competencies, an increase in self-awareness may likely lead to greater multicultural competence (Vinson \& Neimeyer, 2000). This multicultural competence provides a framework for deeper exploration within training programs as well as the encouragement of counselor trainees to cultivate their own self-awareness.

\section{Societal Implications}

The suggestion that pilgrimage has far-reaching societal implications has been noted by previous researchers (e.g., Collins-Kreiner, 2009; Turner, 1978; Winkleman \& Dubisch, 2005). In the current study, the societal implications extend beyond the pilgrimage site or the meaning for the local inhabitants (McKevitt, 1991). The act of hearing about one's pilgrimage experience creates meaning at the individual level. There is also something inherently therapeutic in the act of storytelling (Dwivedi, 1997; Land, 2007). This act of storytelling creates an inexplicable connection between the teller and the listener. This connection extends to the pilgrimage context. Dubisch suggested that individuals want to talk about their pilgrimage experiences when they are asked the right questions (J. S. Dubisch, personal communication, January 27, 2013). Such dialogue about pilgrimage has the potential to bring respect and understanding among individuals who may otherwise categorize themselves as enemies.

Within the counseling context, the topic of pilgrimage could be utilized within a group therapy setting. Group therapy participants who have all been on a pilgrimage could 
share about their experiences and the meaning of these experiences in their lives. Further, dialogue about pilgrimage could be used in counselor training programs as a basis for intercultural conversations. Within a community setting, discussions about pilgrimage could be used to build interfaith, interethnic, and interclass understanding and collaboration.

The feminine and egalitarian qualities of pilgrimage. The participants in this study frequently spoke about their pilgrimages in feminine language. They felt welcomed, cared for, and nurtured during the pilgrimage experience. Said and Ashanti referenced "being comforted" during their pilgrimage experiences. It is interesting to observe that as participation in organized religions declines worldwide, participation in pilgrimage is increasing (Smith \& Puczkó, 2009). There appears to be a connection between the movement towards egalitarianism and pilgrimage. Further, those religions with hierarchical models of religious authority also provide a context for pilgrimage. For example, it is interesting to note that during the Hajj pilgrimage, men and women participate together, wearing the same types of clothes and engaging in rituals not segregated by gender. This phenomenon is in stark contrast to the gender segregated worship that characterizes most of the Islamic world. Additionally, millions of Catholic adherents have participated in pilgrimages all around the globe and have for two thousand years. In both the Muslim and Catholic examples, it is as if the pilgrims welcome the opportunity to leave the traditional roles or structure of their daily or weekly religious practice to embrace that which is anti-structure, consistent with Turner's notion that pilgrimage is an anti-structure endeavor (1969).

With an established pilgrimage paradigm that exists in the world's religions, perhaps there is a foundation for increasing the visibility of women and other marginalized groups 
within more patriarchal structures. Clearly, in the above examples of Muslim and Catholic pilgrimages, men and women participate together. To stifle the accounts of female pilgrims is a detriment to a specific religious culture as well as to humanity in general. It would be a worthwhile endeavor for segregated communities to explore the experiences of all of the pilgrims who participate in a pilgrimage. There are more similarities in these experiences than differences and these should be highlighted.

Awareness of time. The awareness of one's place in time was an interesting finding because it was not specifically address in the prior pilgrimage research. Eight of the ten participants either observed multiple generations of people on the pilgrimage or included themselves within a multi-generational framework. The fact that this type of connection was noted was striking because it emerged as a repeated theme within the participants' accounts and across the participant sample.

Within regards to the implications for counselors, it is critical that counselors inquire about extended familial relationships to gain a more accurate contextual understanding of the client. In Western society, clients are often viewed as individuals and not within a communal structure. That the multi-generational observations were of great importance to the study participants is an indication that intergenerational connection is more significant than may be acknowledged. Moreover, as previously mentioned, multicultural competence reflects a focus on social processes (Sue et al., 1998).

Counselor education training should also focus on the importance of multigenerational social structures within the composition of their students, faculties, and site supervisors. Counselor educators and trainees often interact with others in age or class 
stratified groups and there is much to be learned from engagement with a wide range of individuals that represent different ages of classes. One suggestion is to provide opportunities during classes for topic related panels that feature individuals from different age ranges or class structures. The topic does not have to be limited to pilgrimage; although, this topic provides one significant domain to explore.

\section{Limitations of the Study}

This study was limited with regards to participants and research design:

\section{Participants}

With the goal of broad representation of pilgrimages, this study may have been limited by the number of participants for each type of pilgrimage. As acknowledged, participants assign meaning in different ways to their pilgrimage journeys (Dubisch \& Winkleman, 2005; King, 2005 Morinis, 1992). Thus, the pilgrimage experience for multiple pilgrims visiting identical sites will be varied. Moreover, the number of participants did not fully represent the spectrum of pilgrimage destinations. The data could have been enriched by participants who journeyed on other pilgrimages such as the Camino de Santiago and the Kumbh Mela.

\section{Research design}

Because of the paucity of both pilgrimage theory and pilgrimage data within counseling and psychology, the research design utilized was a basic qualitative design. This method yielded rich results, but could be enhanced by future quantitative or mixed methods studies. Moreover, grounded theory is in its infancy within the field of counseling and 
substantive guidelines for implementations do not exist. Consequently, texts from other disciplines were consulted for appropriate research protocol.

The semi-structured interview items may have also limited the study as the questions may have yielded socially desirable answers. This limitation was addressed by providing the interview template prior to the interview so that participants could reflect on their answers rather than giving spontaneous answers. Because the study explored the therapeutic value of pilgrimage, the questions were not aimed at such objectives as ascertaining the level of a religious adherence or personal thoughts about a particular religion.

\section{Recommendations for Future Research and Practice}

Based on the above observation that pilgrimage is rich with themes of connection, an area for future research is an exploration of connectedness before and after a pilgrimage. For example, future participants could be given a connectedness scale prior to and after a pilgrimage and the results could be analyzed for differences. Also, future research could examine depth of meaning for pilgrimage groups who participated in a group process before and after a pilgrimage and those who did not participate in a group process. In specific, two groups could be studied: the first group would be assigned to a six week pre-pilgrimage course that explored the history of the pilgrimage site as well as focused on types of therapeutic issues such as decision-making, closure, connection, etc. This group would then go on the pilgrimage and, upon return, would go through a three-week reintegration course. The second group would go on the pilgrimage with no pre or post pilgrimage group process.

The possibilities are wide open for the study of the therapeutic value of pilgrimage. Moreover, there may be significant possibilities for specific types of individuals such as 
military veterans, trauma victims, clergy members, and those desiring a deeper connection with their ancestral heritage. One noted scholar affirmed that there is considerable promise for the study of pilgrimage within a therapeutic framework (J.S. Dubisch, personal communication, January 27,2013$)$. On a global scale, the topic of pilgrimage is being explored by many scholars outside the realm of anthropology. One occupational therapy scholar suggested, "Phenomenological investigation of specific pilgrimage experiences at various sites internationally would contribute to understanding this occupation" (Courtney, 2013, p. 8). Researchers at The College of William and Mary have initiated exciting multidisciplinary work on the topic of pilgrimage that involves scholars from kinesiology, Hispanic studies, sociology, and classical studies.

\section{Conclusion}

Thomas Moore asserted, "The great malady of the twentieth century, implicated in all of our troubles and affecting us individually and socially, is 'loss of soul."” (1992, p. xi). Pilgrimage is one antidote for this "loss of soul" and, as demonstrated above, has both individual and social implications. To recognize the profundity of the loss of soul and how deeply the malady has penetrated our world, it is helpful to examine what those at the end of life state about their lives. In a poignant article on what people talk about before they die, hospice chaplain Kerry Egan stated:

They talk about the love they felt, and the love they gave. Often they talk about love they did not receive, or the love they did not know how to offer, the love they withheld, or maybe never felt for the ones they should have loved unconditionally. They talk about how they learned what love is, and what it is 
not. And sometimes, when they are actively dying, fluid gurgling in their throats, they reach their hands out to things I cannot see and they call out to their parents: Mama, Daddy, Mother (CNN Belief Blog, 2012).

As humans, we have the opportunity to gain perspective on what it truly significant in life. Often, death or trauma, forces the issue and we become reoriented on that which really matters, those arenas in our lives that speak to the soul. Pilgrimage is one act that can lead to the same awareness as those near death experiences reflect.

Pilgrimage is a time apart from the routine that provides meaning for that routine. Ultimately, pilgrimage is rich in connection. This connection occurs within the self, with others, and with the site. The connection is present in dialogue about pilgrimage as pilgrimage narratives illuminate the human soul and its motivations, fears, hopes, and dreams. Pilgrimage provides a connection to the past and a link to the future and embodies that which is authentic is our human existence. And pilgrimage connects the beautiful souls within and between classes, religions, ethnicities, and gender.

However, to speak about pilgrimage as a utopian ideal is to miss its darker image. This darkness is found in the notion that pilgrimage reveals the authenticity of the soul. When we exist in a socially constructed reality, our roles and behaviors often conform to that within which we desire to live. During a pilgrimage, these roles are often exposed and a certain level of dissonance may be revealed. Reintegration into the pre-pilgrimage roles may become difficult or, in some cases, impossible. For example, an individual may decide to change a career, end a relationship, convert to another religion, or "come out" as a homosexual as a result of a pilgrimage. Each of these scenarios contains elements of 
confusion, pain, disappointment, and joy. In addition, the scenarios often impact others in the pilgrim's life.

The above examples ought not minimize the significance of a pilgrimage, but rather illustrate its profound meaning for the pilgrim. In both modern and postmodern contexts, linear and nonlinear, pilgrimage provides the opportunity to co-create one's existence and to co-create with a power outside of ourselves. The therapeutic nature of the pilgrimage journey begins when the commitment is made, continues throughout the journey, and is integrated upon the return. As noted by pilgrimage scholars, "That pilgrimage continues to exercise such a strong attraction in the contemporary world is testimony to its power and to its adaptive nature as a ritual and healing process" (Winkleman \& Dubisch, 2005, p. xxxvi). 


\section{REFERENCES}

American Holistic Health Association. (2012). Holistic health. Retrieved from http://ahha.org/articles.asp?Id=85.

Arredondo, P., Toporek, R., Brown, S.P., Jones, J., Locke, D.C., Sanchez, J., \& Stadler, H. (1996). Operationalization of the multicultural counseling competencies. Journal of Multicultural Counseling and Development, 24, 42-78.

Baruth, L. G., \& Manning, M. L. (2003). Multicultural counseling and psychotherapy: A lifespan perspective. ( $3^{\text {rd }}$ ed.). Upper Saddle River, NJ: Pearson.

Bolen, J.S. (1994). Crossing to Avalon: A woman's midlife pilgrimage. San Francisco: HarperSan Francsico.

Bowman, G. (1991). Christian ideology and the image of a holy land. In J. Eade \& M. J. Sallnow (Eds.), Contesting the sacred: The anthropology of pilgrimage (pp. 98-121). Chicago, IL: University of Illinois Press.

Bowman, M. (1993). Drawn to Glastonbury. In I. Reader \& T. Walter (Eds.), Pilgrimage in popular culture (pp. 29-62). London: The Macmillan Press.

Bryant, A. (2002). Re-grounding grounded theory. Journal of Information Technology and Application, 4, 25-42.

Bush, K. (2010). The coming age of antibiotics: Discovery and therapeutic value. Annals of the New York Academy of Sciences, 1213(1), 1-4.

Butt, T. (2011). Social action and personal constructs. Theory \& Psychology, 21, 396-411. 
Carver, C., \& Scheier, M. (1996). Perspectives on personality. Boston: Allyn and Bacon.

Charmaz, K. (2000). Constructivist and objectivist grounded theory. In N. K. Denzin \& Y. S. Lincoln (Eds.), Handbook of qualitative research ( $\left.2^{\text {nd }} \mathrm{ed}\right)(\mathrm{pp} .509-535) . \quad$ Thousand Oaks, CA: Sage.

Charmaz, K. (2006). Constructing grounded theory: A practical guide through qualitative analysis. London: Sage.

Charmaz, K. (2009). Shifting the grounds: Constructivist grounded theory methods. In J. M. Morse, P. N. Stern, J. Corbin, B. Bowers, K. Charmaz, K., \& A. E. Clarke (Eds.), Developing grounded theory: The second generation (pp. 127-193). Walnut Creek, CA: Left Coast Press.

Christian, W. (1989). Person and god in a Spanish valley. New York: Seminar Press.

Coleman, S. (2005). Putting it all together again: Pilgrimage, healing, and incarnation at Walsingham. In J. Dubisch \& M. Winkleman (Eds.), Pilgrimage and healing (pp. 91110). Tucson, AZ: The University of Arizona Press.

Collins-Kreiner, N. (2009). Researching pilgrimage: Continuity and transformations. Annals of Tourism Research, 37, 440-456.

Corbin, J., \& Strauss, A. (2008). Basics of qualitative research. (3rd ed.) Thousand Oaks, CA: Sage.

Courtney, M. (2013). A review of the literature exploring the occupation of contemporary pilgrimage. Journal of Occupational Science. doi:10.1080/14427591.2013.764816. 
Cousineau, P. (1998). The art of pilgrimage: The seeker's guide to making travel sacred. Berkeley, CA: Conari Press.

Davidson, L. K., \& Gitlitz, D. M. (2002). Pilgrimage from the Ganges to Graceland: An encyclopedia. Santa Barbara, CA: ABC-CLIO, Inc.

Denzin, N. K. (1988). Interpretive interactionism. Newbury Park, CA: Sage.

Duba, J. D. (2005). Integrative and biopsychosocial therapy: An interview with Len Sperry, M.D., Ph.D. The Family Journal,13(1), 101.

Dubisch, J. (2005). Healing the wounds that are not visible: A Vietnam veterans' motorcycle pilgrimage. In J. Dubisch \& M. Winkleman (Eds.), Pilgrimage and healing (pp. 135154). Tucson, AZ: The University of Arizona Press.

Dunkel-Schetter, C. (2011). Psychological science on pregnancy: Stress processes, biopsychosocial models, and emerging research issues. Annual Review of Psychology, 62(1), 531.

Durkheim, E. (1947). The elementary forms of the religious life: A study in religious sociology. Glencoe, IL: The Free Press.

Dwivedi, K.N. (1997). The therapeutic use of stories. New York: Routledge.

Eade, J., \& Sallnow, M. J. (1991). Introduction. In J. Eade \& M. J. Sallnow (Eds.), Contesting the sacred: The anthropology of pilgrimage. Chicago, IL: University of Illinois Press.

Egan, K. (2012, Janaury 28). RE: My faith: What people talk about before they die [Web log message]. Retrieved from http://religion.blogs.cnn.com/2012/01/28/my-faithwhat-people-talk-about-before-they-die/. 
Eliade, M. (1963). Myth and reality. New York: Harper \& Row.

Erikson, E.H. (1968). Identity: Youth and crisis. New York: Norton.

Ezzy, D. (2002). Qualitative analysis: Practice and innovation. London: Routledge.

Fisher, B., \& Strauss, A. (1978). The Chicago tradition: Thomas, Park, and their successors. Symbolic Interaction, 1, 5-23.

Fisher, C. (1979). Walsingham lives on. London: Catholic Truth Society.

Feiler, B. (2002). Abraham: A journey to the heart of three faiths. New York: Harper Collins.

Fowler, J. W. (1981). Stages of faith: The psychology of human development and the quest for meaning. New York: HarperCollins Publishers.

Fukuyama, M.A., \& Sevig, T.D. (1999). Integrating spirituality in multicultural counseling. Thousand Oaks, CA: Sage.

Gallup, G., \& Lindsay, D.M. (1999). Surveying the religious landscape: Trends in U.S. beliefs. Harrisburg, PA: Morehouse Publishing.

Gemzöe, L. (2005). The feminization of healing in pilgrimage to Fátima. In J. Dubisch \& M. Winkleman (Eds.), Pilgrimage and healing (pp. 25-48). Tucson, AZ: The University of Arizona Press.

Gerrity, D.A. (2001). A biopsychosocial theory of infertility. The Family Journal, 9(2), 151.

Gilmore, L. (2005). Embers, dust, and ashes: Pilgrimage and healing at the burning man festival. In J. Dubisch \& M. Winkleman (Eds.), Pilgrimage and healing (pp. 155177). Tucson, AZ: The University of Arizona Press. 
Glaser, B. G. (1978). Theoretical sensitivity. Mill Valley, CA: The Sociology Press.

Glaser, B. G. (2002). Conceptualization: On theory and theorizing using grounded theory. International Journal of Qualitative Methods, 1, 1-31.

Glaser, B., \& Strauss, A. (1967). The discovery of grounded theory. Chicago, IL: Aldine.

Gonzalez, R. C. (1997). Postmodern supervision: A multicultural perspective. In D. B. Pope-Davis \& H. L. K. Coleman (Eds.), Multicultural counseling competencies: Assessment, education and training, and supervision (pp. 350-386). Thousand Oaks, CA: Sage.

Gopal, L., \& Dubey, D. P. (Eds.) (1990). Pilgrimage studies: Text and context. Allahabad, India: The Society of Pilgrimage Studies.

Gordon, J. Y. (2011). The therapeutic value of adversity. ASHA Leader, 16(9), 53. Journal of the American Medical Association. (2009). The diagnostic and therapeutic value of lumbar puncture. 301(10), 1077. Author.

Greenfield, S. M., \& Cavalcante, A. M. (2005). Pilgrimage healing in northeast Brazil: A culturalbiological explanation. In J. Dubisch \& M. Winkleman (Eds.), Pilgrimage and healing (pp. 3-23). Tucson, AZ: The University of Arizona Press.

Inui, T.S. (2003). The need for an integrated biopsychosocial approach to research on successful aging. Annals of Internal Medicine, 139(5), 391.

Kantrowitz, J., \& Citrome, L. (2007). Paliperidone: The evidence of its therapeutic value in schizophrenia. Core Evidence, 2, 261-271. 
Kelly, G.A. (1955). The psychology of personal constructs. New York: W. W. Norton.

Kenreigh, C.A., Wagner, L.T., \& Chrisp, P. (2006). Ciclesonide in persistent asthma: The evidence of its therapeutic value. Core Evidence, 1, 232-249.

King, C. L. (2005). Pilgrimage, promises, and ex-votos: Ingredients for healing in northeast Brazil. In J. Dubisch \& M. Winkleman (Eds.), Pilgrimage and healing (pp. 49-68). Tucson, AZ: The University of Arizona Press.

Kohlberg, L. (1981). Essays on moral development, vol. I: The philosophy of moral development, San Francisco, CA: Harper \& Row.

Kottler, J. A., Carlson, J., \& Keeney, B. (2004). American shaman: An odyssey of global healing traditions. New York: Brunner-Routledge.

Kreber, C., Castleden, H., Erfani, N., Lim, J., \& Wright, T. (2003). Exploring the usefulness of Kelly's personal construct theory in assessing student learning in science courses. Teaching in Higher Education, 8, 431-445.

Land, K. (2007). Storytelling as therapy: The motives of a counselor. Business Communication Quarterly, 70(3), 377-381.

Macrae, R., \& Andrew, M. (2011). The use of personal construct theory in work with men who abuse women partners. Probation Journal, 58, 23-36.

Maxwell, J. (1996). Conceptual context. What do you think is going on? Qualitative research design: An interactive approach, (pp. 25-48). Thousand Oaks, CA: Sage.

McCaslin, M. L., \& Scott, K. W. (2003). The five-question model for framing a qualitative research study. The Qualitative Report, 8, 447-461. 
McKevitt, C. (1991). San Giovanni Rotondo and the shrine of Padre Pio. In J. Eade \& M. J. Sallnow (Eds.), Contesting the sacred: The anthropology of pilgrimage (pp.7797). Chicago, IL: University of Illinois Press.

Milliken, P. J. (2010). Grounded theory. In N. J. Salkind (Ed.). Encyclopedia of research design. Thousand Oaks, CA: Sage.

Moore, T. (1992). Care of the soul: A guide for cultivating depth and sacredness in everyday life. New York: HarperPerennial.

Morinis, A. (1992). Sacred journeys: The anthropology of pilgrimage. Westport, CT: Greenwood Press.

Morse, J. M. (2009). Tussles, tensions, and resolutions. In J. M. Morse, P. N. Stern, J. Corbin, B. Bowers, K. Charmaz, K., \& A.E. Clarke (Eds.), Developing grounded theory: The second generation (pp. 13. 22). Walnut Creek, CA: Left Coast Press.

Morse J. M., \& Field P. A. (1995) Qualitative research methods for health professionals $\left(2^{\text {nd }}\right.$ ed.). London: Sage.

Morse, J. M., \& Singleton, J. (2011). Exploring the technical aspects of fit in qualitative research. Qualitative Health Research, 11, 841-847.

Morse, J. M., Stern, P. N., Corbin, J., Bowers, B., Charmaz, K., Clarke, A.E. (Eds.). (2009). Developing grounded theory: The second generation. Walnut Creek, CA: Left Coast Press.

Nagashima, H., \& Kasanuki, H. (2003). Therapeutic value of statins for vascular remodeling. Current Vascular Pharmacology, 1, 273-279. 
Notermans, C. (2007). Loss and healing: A Marian pilgrimage in secular Dutch society. Ethnology, 46, 1-17.

O’Sullivan, B. (2007). Nasopharynx cancer: Therapeutic value of chemoradiotherapy. International Journal of Radiation Oncology, Biology, Physics, 69, 118-121.

Pace, E. (1989). Pilgrimage as spiritual journey: An analysis of pilgrimage using the theory of V. Turner and the resource mobilization approach. Social Compass, 36, 229-244.

Patton, M. (2002). Qualitative research and evaluation methods. Thousand Oaks, CA: Sage.

Piaget, J. $(1936,1963)$ The origins of intelligence in children. New York: W. W. Norton.

Prus, R.C. (1995). Symbolic interaction and ethnographic research: Intersubjectivity and the study of human lived experience. Albany, NY: State University of New York Press.

Reeves, B. (1997). Ninaistákis - the Nitsitapii’s sacred mountain: Traditional native religious activities and land use/tourism conflicts. In D. Carmichael, J Hubert, B. Reeves, \& A. Schanche (Eds.), Sacred sites, sacred places (pp. 265-295). London: Routledge.

Salkind, N. J. (2010). Encyclopedia of research design. Thousand Oaks, CA: Sage.

Sandage, S. J., Jankowski, P. J., \& Link, D. C. (2010). Quest and spiritual development moderated by spiritual transformation. Journal of Psychology and Theology, $38(1), 15-31$.

Sered, S. (2005). Exile, illness, and gender in Israeli pilgrimage narratives. In J. Dubisch \& M. Winkleman (Eds.), Pilgrimage and healing (pp. 69-89). Tucson, AZ: The University of Arizona Press. 
Smith, M., \& Puczkó, L. (2009). Health and wellness tourism. Burlington, MA: Elsevier.

Spencer, J., \& Spencer, A. (2002). The encyclopedia of the world's mystical and sacred sites. London: Headline Book Publishing.

Strachan, A., \& Jones, D. (1982). Changes in identification during adolescence: A personal construct theory approach. Journal of Personality Assessment, 46, $529-535$.

Strauss, A., \& Corbin, J. (1990). Basics of qualitative research: Grounded theory procedures and techniques. Newbury Park, CA: Sage.

Strauss, A., \& Corbin, J. (1998). Basics of qualitative research: Grounded theory procedures and techniques ( $2^{\text {nd }}$ ed.). Thousand Oaks, CA: Sage.

Sue, D. W., Carter, R. T., Casas, J. M., Fouad, N. A., Ivey, A. E., Jensen, M., LaFromboise, T., Manese, J. E., Ponterotto, J. G., Vazquez-Nutall, E. (1998). Multicultural counseling competencies: Individual and organizational development. Thousand Oaks, CA: Sage.

Sue, D. W., \& Sue, D. (2008). Counseling the culturally diverse: Theory and practice $\left(5^{\text {th }}\right.$ ed.). Hoboken, NJ: John Wiley \& Sons.

Sulmasy, D.P. (2002). A biopsychosocial-spiritual model for the care of patients at the end of life. The Gerontologist, 42(3), 24.

Thomas, S., Butler, R., Hare, D.J., \& Green, D. (2011). Using personal construct theory to explore self-image with adolescents with learning disabilities. British Journal of Learning Disabilities, 39, 225.232. 
Turner, V. (1969). The ritual process: Structure and anti-structure. Chicago: Aldine Publishing Company.

Turner, V. (1974). Dramas, fields, and metaphors: Symbolic action in human society. Ithaca, NY: Cornell University Press.

Turner, V., \& Turner, E. (1978). Image and pilgrimage in Christian culture. New York: Columbia University Press.

Vinson, T. S., \& Neimeyer, G. J. (2000). The relationship between racial identity development and multicultural counseling competency. Journal of Multicultural Counseling and Development, 28(3), 177-192.

Walter, T. (1993). War grave pilgrimage. In I. Reader \& T. Walter, (Eds.), Pilgrimage in popular culture (pp. 63-91). Basingstoke, England: MacMillan.

Webster's II: New College Dictionary. (2001). Boston, MA: Houghton Mifflin Company. Author.

Winkelman, M., \& Dubisch, J. (2005). Introduction: The anthropology of pilgrimage. In J. Dubisch \& M. Winkleman (Eds.), Pilgrimage and healing (pp. ix-xxxvi). Tucson, AZ: The University of Arizona Press.

Zhou, F. (2009). Review of vegetables and fruits: Nutritional and therapeutic values. Journal of Agricultural \& Food Information, 10, 80. 
APPENDICES 


\section{APPENDIX A: INTERVIEW ITEMS}

\section{The Therapeutic Value of Pilgrimage: A Grounded Theory Study}

\section{Section I: Interview Questions}

\section{Purpose of the Study}

Thank you for your time completing the following study. It is anticipated that your participation in this study will help increase the understanding of the overall pilgrimage journey and how pilgrimage may be therapeutic.

Instructions: I am going to ask you about your pilgrimage experience and want to hear about the experience as well as the meaning you made about the experience.

1. What motivated you to go on a pilgrimage?

2. What did you hope would happen during your pilgrimage?

3. What made your journey a pilgrimage?

4. Would you classify your pilgrimage as religious or secular or both?

What about your pilgrimage made this the case?

5. Did you go on your pilgrimage alone or with others?

What influenced your decision for this?

6. Describe your overall pilgrimage experience.

7. Please describe how you made an initial commitment to your pilgrimage journey.

In what way was your initial commitment to the pilgrimage journey therapeutic for you?

8. Please describe how you prepared for your pilgrimage journey.

In what way was the preparation for your pilgrimage therapeutic for you?

9. Please describe your actual pilgrimage journey.

In what way was the actual pilgrimage journey therapeutic for you? 
10. Please describe the experience of entering the pilgrimage site in your pilgrimage journey.

In what way was the experience of entering the pilgrimage site in your pilgrimage therapeutic for you?

11. Please describe the experience of preparing to enter the pilgrimage site on your pilgrimage journey.

In what way was preparing to enter the pilgrimage site on your pilgrimage therapeutic for you?

12. Please describe the experience of being at the pilgrimage site on your pilgrimage journey.

In what way was the experience of being at the pilgrimage site on your pilgrimage therapeutic for?

13. Please describe the experience of leaving the pilgrimage site in your pilgrimage journey.

In what way was the experience of leaving the pilgrimage site on your pilgrimage therapeutic for you?

14. Please describe the experience of returning home after your pilgrimage journey.

In what way was the experience of returning home after your pilgrimage therapeutic for you?

15. Is there anything else about your pilgrimage experience that you would like to share with me? 


\section{Section II: Demographic Information}

Instructions: Please complete the following demographic questions by selecting the appropriate response(s) to each question or by providing information in the space provided.

1. Age
○ 18-21 years old
○ 35-39 years old
○ 55-59 years old
○ 22-25 years old
○ 40-44 years old
○ 60-64 years old
○ 26-29 years old
○ 45-49 years old
○ 65-69 years old
○ 30-34 years old
○ 50-54 years old
○ 70-74 years old
○ $75+$ years old

\section{Ethnicity}
O African American
O Latino American
O Asian American
○ Pacific Islander
○ Caucasian
O Other:

\section{Gender}

O Female

○ Male

\section{Highest education completed}

○ High school

O Some college

○ Bachelor's degree

○ Master's degree

○ Doctoral degree

Other

\section{What is your religion (if any)?}

5. In what ways do you practice your religion and/or spirituality? 


\section{APPENDIX B: INTERVIEW INFORMED CONSENT FORM}

\section{North Carolina State University INFORMED CONSENT FORM for RESEARCH}

Title of Study The Therapeutic Value of Pilgrimage: A Grounded Theory Study Principal Investigator Heather A. Warfield, MA, NCC

Faculty Sponsors Dr. Stanley B. Baker and Dr. Sejal B. Parikh

\section{What are some general things you should know about research studies?}

You are being asked to take part in a research study. Your participation in this study is voluntary. You have the right to be a part of this study, to choose not to participate, or to stop participating at any time without penalty. The purpose of this research study is to gain a better understanding of the therapeutic value of pilgrimage. You are not guaranteed any personal benefits from being in a study. This study may pose risks to those that participate. In this consent form, you will find specific details about the research in which you are being asked to participate. If you do not understand something in this form, it is your right to ask the researcher for clarification or more information. A copy of this consent form will be provided to you. If at any time you have questions about your participation, do not hesitate to contact the researcher(s) named above.

\section{What is the purpose of this study?}

It is anticipated that your participation in this study will help increase the understanding of the overall pilgrimage journey and how pilgrimage may be therapeutic.

\section{What will happen if you take part in the study?}

If you agree to participate in this study, you will be asked to answer questions about your pilgrimage experience. The interview will be recorded and transcribed. It is expected that the interview will last approximately one (1) hour. The interview will take place in an office space during a time that is agreed upon by the researcher and the participant.

\section{$\underline{\text { Risks }}$}

The interview items may produce stress or anxiety for some participants. If you become upset at any point during the interview, the interview can be stopped immediately. If you would like to speak to a counselor about your experience, a referral will be given.

\section{$\underline{\text { Benefits }}$}

Benefits from participating in this study may include: a greater value placed on your

pilgrimage experience; contribution to the body of knowledge about pilgrimage; and improvement of the counseling profession through the development of counseling practices based on knowledge gained during this study. 


\section{Confidentiality}

You will be assigned a pseudonym to mask your identity. However, verbatim quotes will be used in reporting the results. The information in the study records will be kept confidential to the full extent allowed by law. Data will be stored securely stored on a password protected and encrypted computer storage drive for the interview recordings until transcribed. Once transcribed, the recordings will be deleted. The interview transcripts will be securely stored on a password protected and encrypted computer storage drive. You will NOT be asked to write your name on any study materials so that no one can match your identity to the answers that you provide.

\section{Compensation}

As an incentive for participating, you will have the opportunity to have your name entered into a random drawing for a \$25 Visa gift card. Chances for winning the gift card will depend on the total number of participants, but will be no less than a 1 in 30 chance to win with the possibility of a greater chance to win if there are fewer participants. Participants who choose to enter the drawing will have their name and email address entered into a database used for selection of the winner. Participants can opt out of the incentive drawing by letting the Principal Investigator know of this choice.

\section{What if you have questions about this study?}

If you have questions at any time about the study or the procedures, you may contact the researcher, Heather A. Warfield, hawarfie@ncsu.edu, or [919.434.5730].

\section{What if you have questions about your rights as a research participant?}

If you feel you have not been treated according to the descriptions in this form, or your rights as a participant in research have been violated during the course of this project, you may contact Deb Paxton, Regulatory Compliance Administrator, Box 7514, NCSU Campus [919.515.4514].

\section{Consent To Participate}

"I have read and understand the above information. I have received a copy of this form. I agree to participate in this study with the understanding that I may choose not to participate or to stop participating at any time without penalty or loss of benefits to which I am otherwise entitled." 


\section{APPENDIX C: TABLE}

Table 1

Initial, Focused, Axial, and Theoretical Codes Identified During Analysis

\begin{tabular}{|c|c|c|c|}
\hline Initial Codes & Focused Codes & Axial Codes & Theoretical Codes \\
\hline $\begin{array}{l}\text { Eating } \\
\text { Praying } \\
\text { Walking } \\
\text { Bringing home a moment }\end{array}$ & $\begin{array}{l}\text { Using body to engage } \\
\text { the pilgrimage experience }\end{array}$ & $\begin{array}{l}\text { Physical or } \\
\text { biological connection }\end{array}$ & $\begin{array}{l}\text { Biological } \\
\text { (therapeutic value) }\end{array}$ \\
\hline $\begin{array}{l}\text { Making meaning } \\
\text { Making a decision } \\
\text { Feeling welcomed } \\
\text { Becoming aware } \\
\text { Marking time } \\
\text { Reflecting } \\
\text { Being comforted } \\
\text { Contrasting } \\
\text { Gaining knowledge } \\
\text { Gaining perspective } \\
\text { Witnessing serendipitous }\end{array}$ & $\begin{array}{l}\text { Connecting with self } \\
\text { Connecting with others } \\
\text { Connecting with history } \\
\text { Contrasting } \\
\text { Figuring out priorities } \\
\text { Recharging batteries* }\end{array}$ & $\begin{array}{l}\text { Psychological connection } \\
\text { Recalibrate* } \\
\text { Contrast }\end{array}$ & $\begin{array}{l}\text { Psychological } \\
\text { (therapeutic value) }\end{array}$ \\
\hline $\begin{array}{l}\text { Observing others } \\
\text { Forming group identity } \\
\text { Participating in ritual } \\
\text { Giving back to others at } \\
\text { pilgrimage site } \\
\text { Connecting } \\
\text { Recognizing generational } \\
\text { legacy } \\
\text { Going home }\end{array}$ & $\begin{array}{l}\text { Observing others } \\
\text { Connecting with others } \\
\text { Connecting with self } \\
\text { Connecting with history }\end{array}$ & $\begin{array}{l}\text { Legacy } \\
\text { Homecoming } \\
\text { Social connection }\end{array}$ & $\begin{array}{l}\text { Social } \\
\text { (therapeutic value) }\end{array}$ \\
\hline $\begin{array}{l}\text { Praying } \\
\text { Connecting } \\
\text { Contrasting }\end{array}$ & $\begin{array}{l}\text { Connecting with God } \\
\text { Connecting with self }\end{array}$ & Spiritual connection & $\begin{array}{l}\text { Spiritual } \\
\text { (therapeutic value) }\end{array}$ \\
\hline
\end{tabular}

* in vivo code 